\title{
Engineering Functionalization in a Supramolecular Polymer: Hierarchical Self-Organization of Triply Orthogonal Non-Covalent Interactions on a Supramolecular Coordination Complex Platform
}

\author{
Zhixuan Zhou, ${ }^{\dagger}$ Xuzhou Yan, ${ }^{* \dagger}$ Timothy R. Cook, ${ }^{\ddagger}$ Manik Lal Saha, ${ }^{\dagger}$ and Peter J. Stang, ${ }^{* \dagger}$ \\ ${ }^{\dagger}$ Department of Chemistry, University of Utah, 315 South 1400 East, Room 2020, Salt Lake City, Utah 84112, United \\ States \\ ${ }^{\ddagger}$ Department of Chemistry, University at Buffalo, 359 Natural Sciences Complex, Buffalo, New York 14260, United \\ States \\ Email addresses: x.yan@utah.edu; stang@chem.utah.edu
}

\section{Supporting Information}

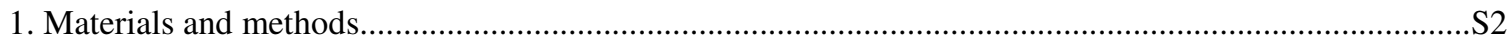

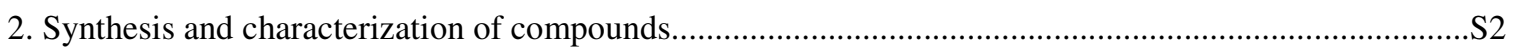

3. DOSY NMR experiments of crown ether functionalized hexagon $\mathbf{6}$ and supramolecular network $\mathbf{1}$ at 10.0 $\mathrm{mM}$

4. Comparison of ${ }^{1} \mathrm{H}$ NMR spectra of network 1 in $\mathrm{CD}_{2} \mathrm{Cl}_{2} / \mathrm{CD}_{3} \mathrm{NO}_{2}(1: 1 \mathrm{v} / \mathrm{v})$ and DMSO- $d_{6} \ldots \ldots \ldots \ldots \ldots . . . . . . . . . .17$

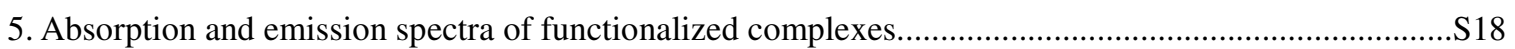

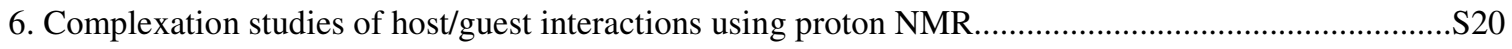

7. Self-healing properties of the supramolecular polymer network gel...................................................S23

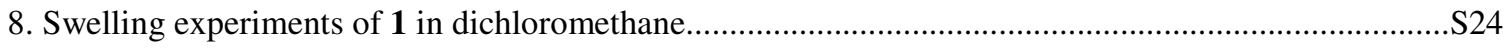

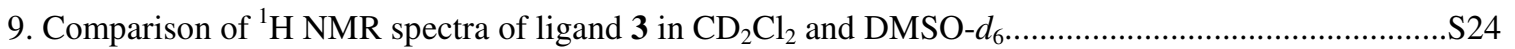




\section{Materials and methods}

All reagents were commercially available and used as supplied without further purification. Deuterated solvents were purchased from Cambridge Isotope Laboratory (Andover, MA). Compounds $3,{ }^{\mathrm{S} 1} \mathbf{S 1},{ }^{\mathrm{S} 2} \mathbf{S 2},{ }^{\mathrm{S} 3}$ and $\mathbf{S 4}{ }^{\mathrm{S} 4}$ were prepared according to the published procedures. ${ }^{1} \mathrm{H}$ NMR and ${ }^{13} \mathrm{C}$ NMR spectra were recorded on a VarianInova $400 \mathrm{MHz}$ spectrometer. ${ }^{31} \mathrm{P}\left\{{ }^{1} \mathrm{H}\right\}$ NMR spectra were recorded on a Varian Unity $300 \mathrm{MHz}$ spectrometer. ${ }^{1} \mathrm{H}$ and ${ }^{13} \mathrm{C}$ NMR chemical shifts are reported relative to residual solvent signals, and ${ }^{31} \mathrm{P}\left\{{ }^{1} \mathrm{H}\right\}$ NMR chemical shifts are referenced to an external unlocked sample of $85 \% \mathrm{H}_{3} \mathrm{PO}_{4}(\delta 0.0)$. Melting points (uncorrected) were obtained with a Mel-Temp capillary melting point apparatus. The two-dimensional diffusion-ordered (2D DOSY) NMR spectra were recorded on a Varian Inova $500 \mathrm{MHz}$ spectrometer. Dynamic light scattering (DLS) experiments were carried out on a NICOMP 380 particle sizing system at room temperature. Mass spectra were recorded on a Micromass Quattro II triple-quadrupole mass spectrometer using electrospray ionization with a MassLynx operating system. Scanning electron microscopy (SEM) investigations were carried out on a JEOL 6390LV instrument. Absorption spectra were recorded on a Hitachi U-4100 spectrophotometer. Fluorescence spectra were recorded on a Hitachi F-7000 Fluorescence Spectrophotometer.

\section{Synthesis and characterization of compounds}

2.1 Synthesis of $4 a$

Scheme S1. Synthesis of 4 a.

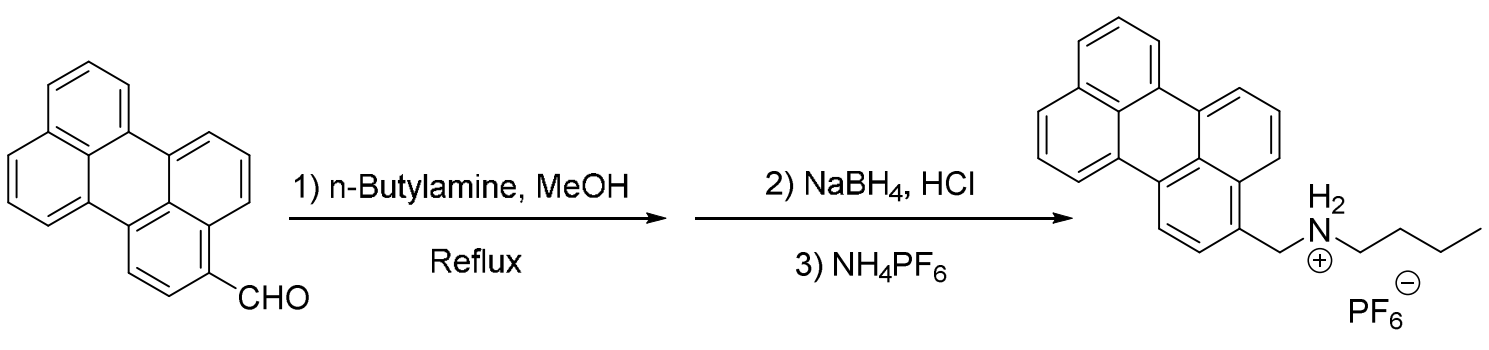

4a

A solution of $n$-butylamine $(219 \mathrm{mg}, 3.00 \mathrm{mmol}$ ) and perylene-3-carbaldehyde ( $841 \mathrm{mg}, 3.00 \mathrm{mmol})$ was heated under reflux overnight in $\mathrm{MeOH}(150 \mathrm{~mL})$. After the reaction mixture was cooled to ambient temperature, $\mathrm{NaBH}_{4}(455 \mathrm{mg}, 12.00 \mathrm{mmol})$ was added portionwise to the stirring solution over a period of $0.5 \mathrm{~h}$. Stirring was maintained under ambient conditions for further $4 \mathrm{~h}$. The mixture was filtered and $\mathrm{MeOH}$ was removed with a rotaevaporator and the residue was dissolved in $\mathrm{CH}_{3} \mathrm{Cl}$. Then it was washed with $1 \mathrm{M}$ aq. $\mathrm{NaOH}$. The organic layer was collected and solvents was removed with a rotaevaporator to afford a yellow oil. After the oil was added to a hydrochloric acid solution and stirred for a moment, a white precipitate formed. The mixture was filtered and the solid was dissolved in hot distilled water to get a saturated solution. The solution was added to a saturated aqueous $\mathrm{NH}_{4} \mathrm{PF}_{6}$ solution to produce a precipitate, which was collected by suction filtration and recrystallized from distilled water to afford $4 \mathbf{a}(1.02 \mathrm{~g}, 70 \%)$ as a yellow solid, mp $226-228{ }^{\circ} \mathrm{C}$. The ${ }^{1} \mathrm{H}$ NMR spectrum of $4 \mathbf{a}$ is shown in Figure S1. ${ }^{1} \mathrm{H}$ NMR (400 MHz, $\left.\mathrm{CD}_{3} \mathrm{CN}, 298 \mathrm{~K}\right) \delta(\mathrm{ppm}): 8.40-$ $8.25(\mathrm{~m}, 4 \mathrm{H}), 7.96(\mathrm{~d}, J=8.3 \mathrm{~Hz}, 2 \mathrm{H}), 7.85-7.75(\mathrm{~m}, 2 \mathrm{H}), 7.70-7.50(\mathrm{~m}, 4 \mathrm{H}), 4.43(\mathrm{~s}, 2 \mathrm{H}), 3.06-3.00$ 
(m, 2H), 1.70-1.60 (m, 2H), 1.46-1.36 (m, 2H), $0.96(\mathrm{t}, J=7.3 \mathrm{~Hz}, 3 \mathrm{H})$. The ${ }^{13} \mathrm{C}$ NMR spectrum of 4a is shown in Figure S2. ${ }^{13} \mathrm{C}$ NMR $\left(100 \mathrm{MHz}\right.$, DMSO- $\left.d_{6}, 298 \mathrm{~K}\right) \delta(\mathrm{ppm}): 134.66,134.64,133.00$, $132.08,132.06,131.37,131.20,130.81,130.65,128.87,128.60,128.07,127.59,127.43,127.41$, 124.36, 121.43, 121.38, 121.30, 120.60, 49.25, 48.42, 29.71, 20.11, and 14.15. HRESIMS: m/z calcd. for $\left[\mathrm{M}-\mathrm{PF}_{6}\right]^{+} \mathrm{C}_{31} \mathrm{H}_{32} \mathrm{~N}$ 338.1903, found 338.1921.

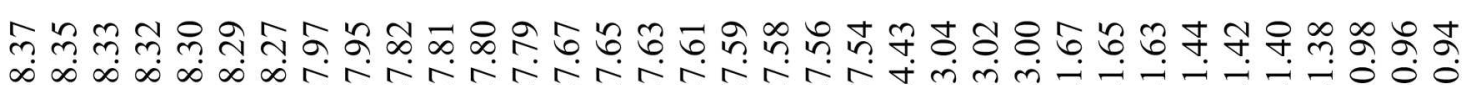

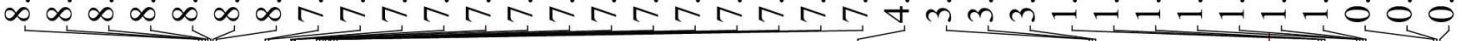

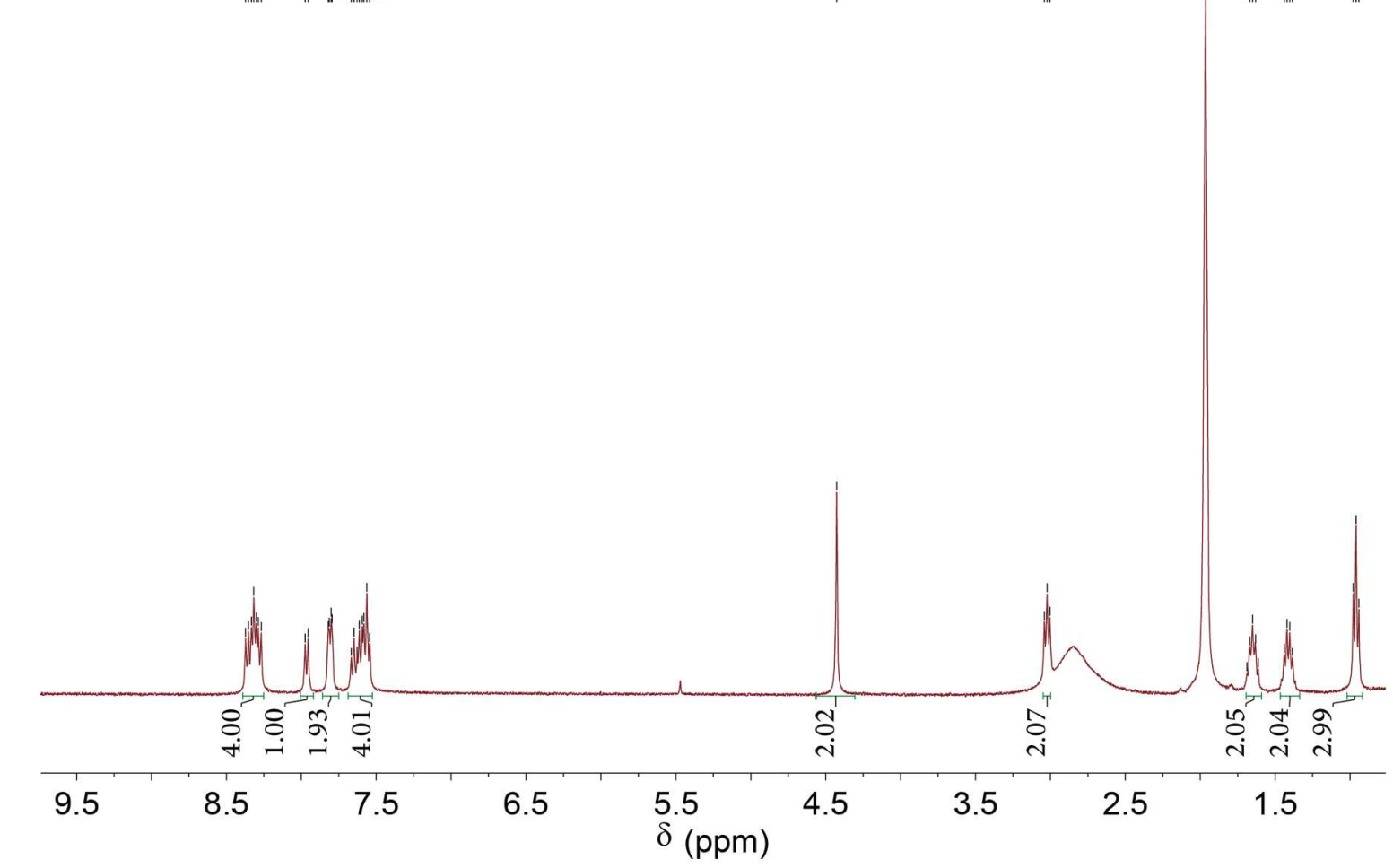

Figure S1. ${ }^{1} \mathrm{H}$ NMR spectrum $\left(400 \mathrm{MHz}, \mathrm{CD}_{3} \mathrm{CN}, 298 \mathrm{~K}\right)$ of $4 \mathbf{a}$. 


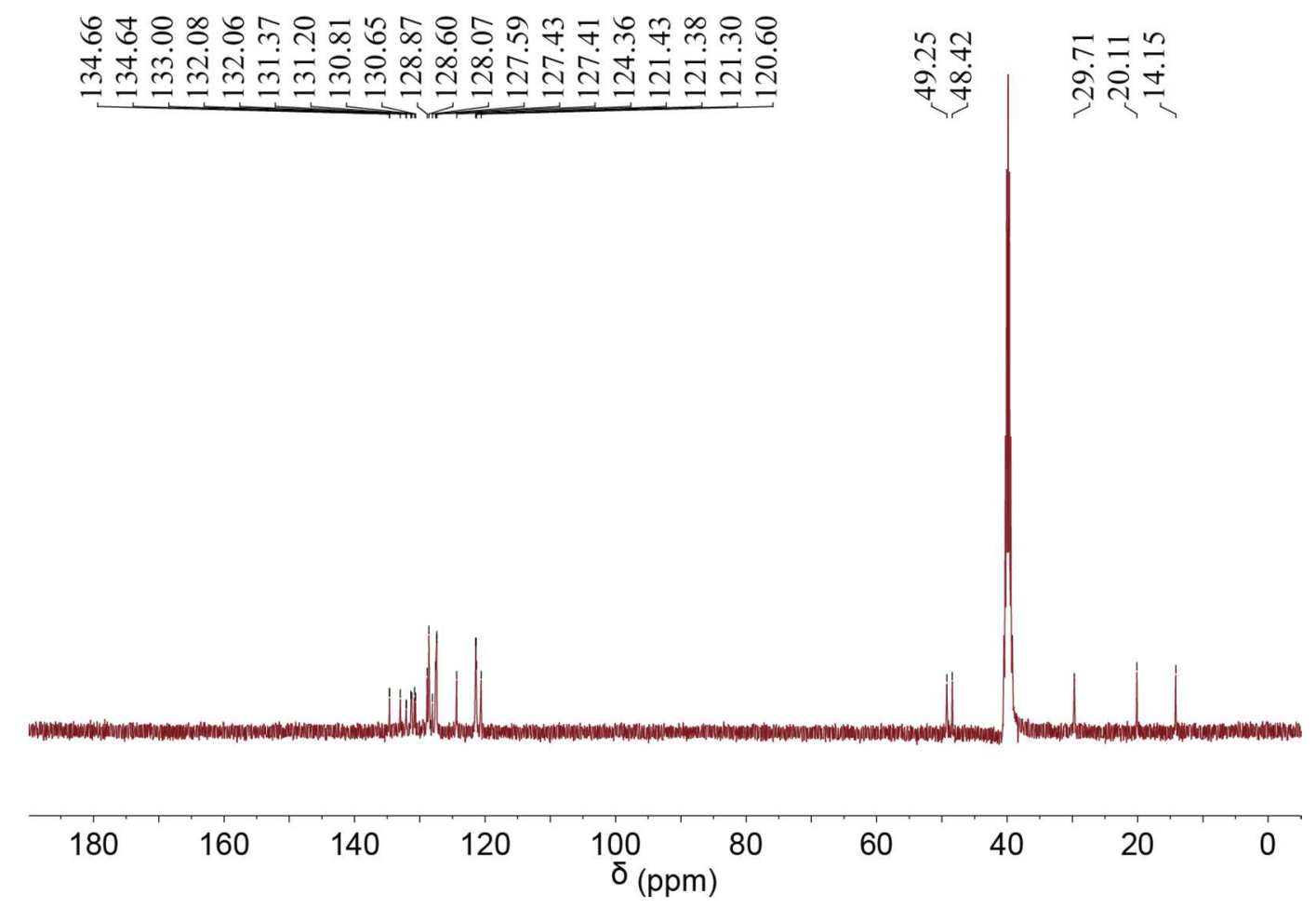

Figure S2. ${ }^{13} \mathrm{C}$ NMR spectrum $\left(100 \mathrm{MHz}\right.$, DMSO- $\left.d_{6}, 298 \mathrm{~K}\right)$ of $\mathbf{4 a}$.

\subsection{Synthesis of $\mathbf{4 b}$}

Scheme S2. Synthesis of $\mathbf{4 b}$.

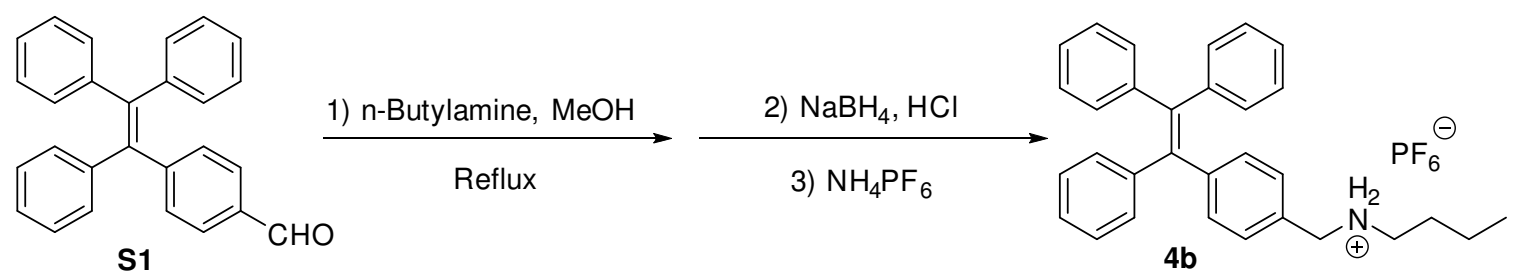

A solution of $n$-butylamine $(146 \mathrm{mg}, 2.00 \mathrm{mmol})$ and $\mathbf{S 1}(721 \mathrm{mg}, 2.00 \mathrm{mmol})$ was heated under reflux overnight in $\mathrm{MeOH}(125 \mathrm{~mL})$. After the reaction mixture was cooled to ambient temperature, $\mathrm{NaBH}_{4}(303 \mathrm{mg}, 8.00 \mathrm{mmol}$ ) was added portionwise to the stirring solution over a period of $0.5 \mathrm{~h}$. Stirring was maintained under ambient conditions for further $4 \mathrm{~h}$. The mixture was filtered and $\mathrm{MeOH}$ was removed with a rotaevaporator and the residue was dissolved in $\mathrm{CHCl}_{3}$. Then it was washed with $1 \mathrm{M}$ aq. $\mathrm{NaOH}$. The organic layer was collected and solvents was removed with a rotaevaporator to afford a yellow oil. After the oil was added to a hydrochloric acid solution and stirred for a moment, a white precipitate formed. The mixture was filtered and the solid was dissolved in hot distilled water to get a saturated solution. The solution was added to a saturated aqueous $\mathrm{NH}_{4} \mathrm{PF}_{6}$ solution to produce a precipitate, which was collected by suction filtration and recrystallized from distilled water to afford 4b (730 mg, 64.8\%) as a white solid, mp 231-233 ${ }^{\circ} \mathrm{C}$. The ${ }^{1} \mathrm{H}$ NMR spectrum of $\mathbf{4 b}$ is shown in Figure S3. ${ }^{1} \mathrm{H}$ NMR (400 MHz, $\left.\mathrm{CD}_{3} \mathrm{CN}, 298 \mathrm{~K}\right) \delta(\mathrm{ppm}): 7.22(\mathrm{~d}, J=8.3 \mathrm{~Hz}, 2 \mathrm{H}), 7.20-7.12(\mathrm{~m}, 11 \mathrm{H}), 7.11-$ $7.02(\mathrm{~m}, 6 \mathrm{H}), 6.62(\mathrm{~s}, 2 \mathrm{H}), 2.98-2.92(\mathrm{~m}, 2 \mathrm{H}), 1.66-1.57$ (m, 2H), 1.43-1.32 (m, 2H), 0.94 (t, $J=7.4$ 
$\mathrm{Hz}, 3 \mathrm{H})$. The ${ }^{13} \mathrm{C}$ NMR spectrum of $\mathbf{4 b}$ is shown in Figure S4. ${ }^{13} \mathrm{C}$ NMR $\left(100 \mathrm{MHz}, \mathrm{CD}_{3} \mathrm{CN}, 298 \mathrm{~K}\right) \delta$ (ppm): 145.23, 143.38, 143.31, 143.27, 141.96, 140.12, 131.46, 130.85, 130.81, 130.78, 129.44, 128.54, 127.85, 127.80, 127.77, 126.69, 51.07, 47.45, 27.44, 19.28, and 12.70. HRESIMS: m/z calcd. for $\left[\mathrm{M}-\mathrm{PF}_{6}\right]^{+} \mathrm{C}_{31} \mathrm{H}_{32} \mathrm{~N}$ 418.2529, found 418.2542.
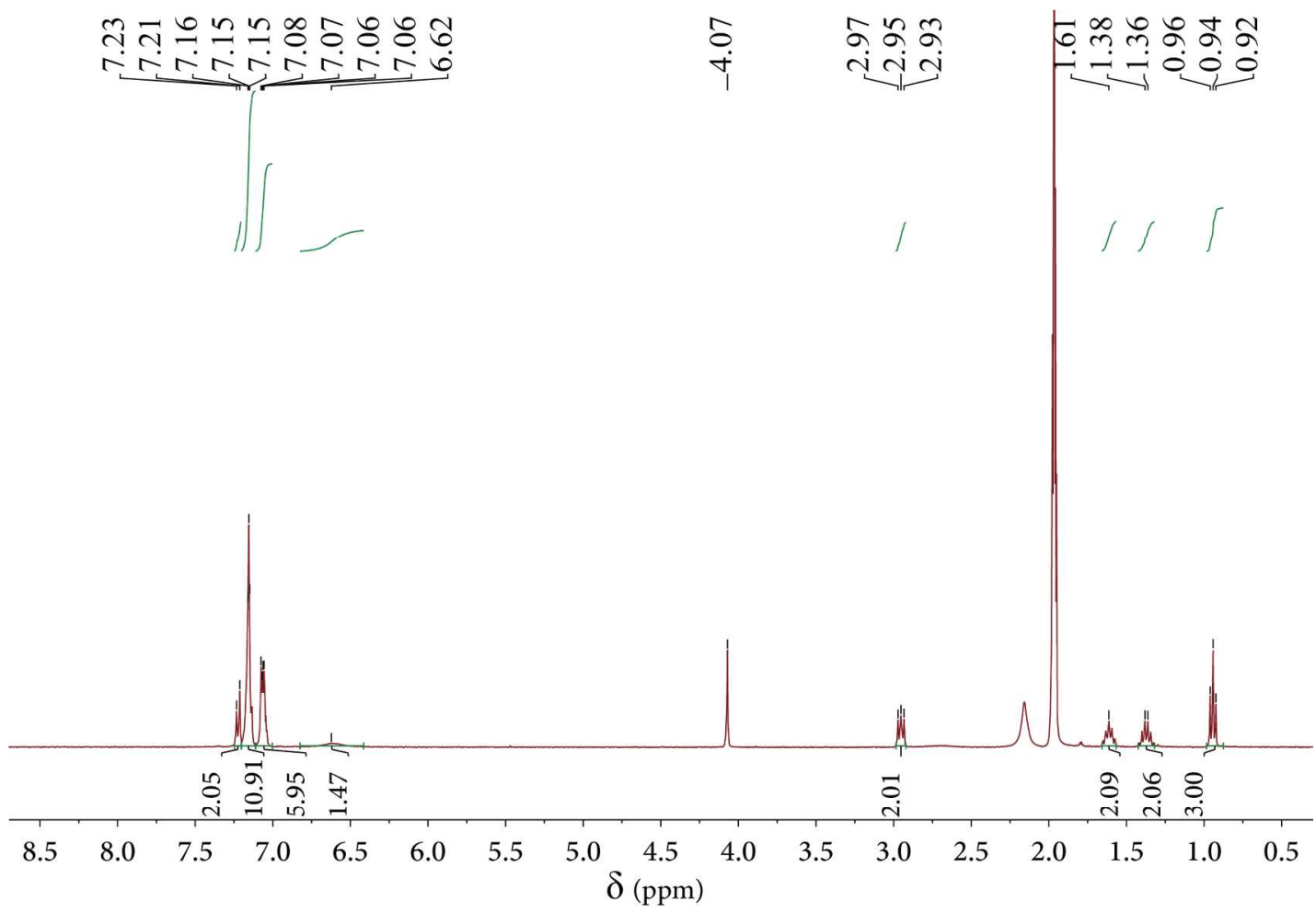

Figure S3. ${ }^{1} \mathrm{H}$ NMR spectrum $\left(400 \mathrm{MHz}, \mathrm{CD}_{3} \mathrm{CN}, 298 \mathrm{~K}\right)$ of $\mathbf{4 b}$. 


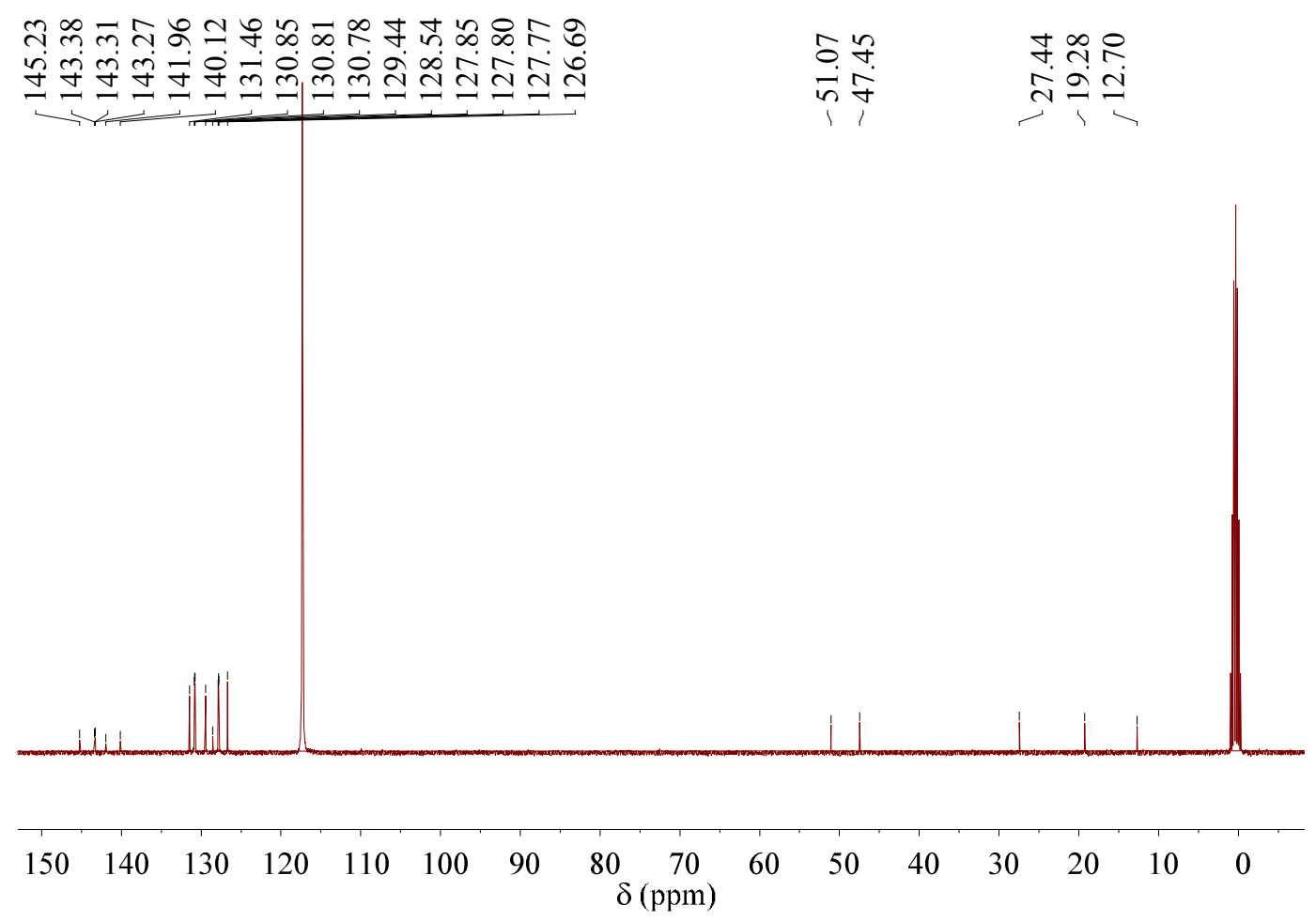

Figure S4. ${ }^{13} \mathrm{C}$ NMR spectrum (100 MHz, $\left.\mathrm{CD}_{3} \mathrm{CN}, 298 \mathrm{~K}\right)$ of $\mathbf{4 b}$.

\subsection{Synthesis of diiodo metal complex $\mathbf{S} \mathbf{3}$}

Scheme S3. Synthesis of 6

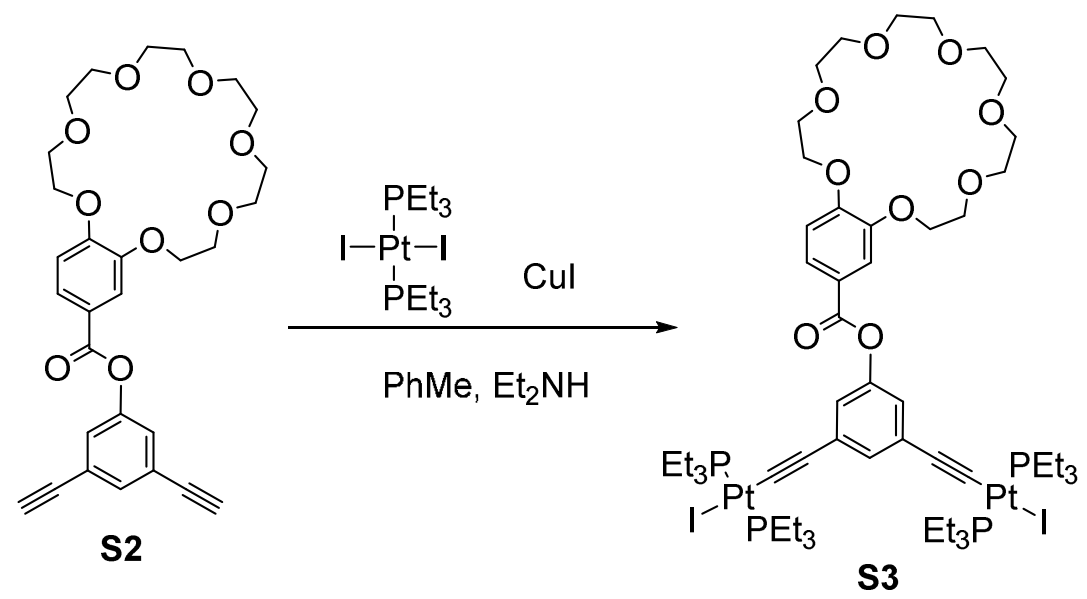

To a $50 \mathrm{~mL}$ round-bottom Schlenk flask were added trans-diiodobis(triethylphosphine-)platinum (820 $\mathrm{mg}, 1.2 \mathrm{mmol}$ ) and $\mathbf{S 2}(262 \mathrm{mg}, 0.5 \mathrm{mmol})$. Then $25 \mathrm{~mL}$ of toluene and $10 \mathrm{~mL}$ of dry diethylamine were added under nitrogen. The solution was stirred for $10 \mathrm{~min}$ at room temperature before $10 \mathrm{mg}$ of cuprous iodide was added in one portion. After $16 \mathrm{~h}$ at room temperature, the solvent was removed under vacuum, the resulting yellow residue was separated by column chromatography on silica gel using dichloromethane and methanol (100:1) as the mobile phase. S3 (475 mg, 58\%) was obtained as an off-white solid, mp $130-131^{\circ} \mathrm{C}$. The ${ }^{1} \mathrm{H}$ NMR spectrum of $\mathbf{S 3}$ is shown in Figure S5. ${ }^{1} \mathrm{H}$ NMR (400 
$\left.\mathrm{MHz}, \mathrm{CD}_{2} \mathrm{Cl}_{2}, 298 \mathrm{~K}\right) \delta(\mathrm{ppm}): 7.82(\mathrm{~d}, J=8.4 \mathrm{~Hz}, 1 \mathrm{H}), 7.68(\mathrm{~s}, 1 \mathrm{H}), 7.10(\mathrm{~s}, 1 \mathrm{H}), 6.99(\mathrm{~d}, J=8.3 \mathrm{~Hz}$, $1 \mathrm{H}), 6.89$ (s, 2H), 4.29-4.19 (m, 4H), 3.96-3.87 (m, 4H), 3.79-3.72 (m, 4H), 3.71-3.66 (m, 4H), 3.65$3.59(\mathrm{~m}, 8 \mathrm{H}), 2.30-2.13(\mathrm{~m}, 24 \mathrm{H}), 1.27-1.10(\mathrm{~m}, 36 \mathrm{H})$. The ${ }^{31} \mathrm{P}\left\{{ }^{1} \mathrm{H}\right\}$ NMR spectrum of $\mathbf{S 3}$ is shown in Figure S6. ${ }^{31} \mathrm{P}\left\{{ }^{1} \mathrm{H}\right\}$ NMR (121.4 MHz, $\left.\mathrm{CD}_{2} \mathrm{Cl}_{2}, 298 \mathrm{~K}\right) \delta(\mathrm{ppm}): 8.74\left(\mathrm{~s},{ }^{1} J_{\mathrm{Pt}-\mathrm{P}}=2309.0 \mathrm{~Hz}\right)$. The ${ }^{13} \mathrm{C}$ NMR spectrum of 6 is shown in Figure S7. ${ }^{13} \mathrm{C}$ NMR (100 MHz, $\left.\mathrm{CD}_{2} \mathrm{Cl}_{2}, 298 \mathrm{~K}\right) \delta$ (ppm): 164.70, 153.56, 150.84, 148.41, 130.32, 129.42, 124.48, 122.04, 121.01, 114.89, 112.28, 109.99, 99.07, 91.37, $71.09,70.98,70.85,70.81,70.75,70.74,70.46,69.51,69.35,69.28,68.96,16.57$, and 8.03. HRESIMS: $\mathrm{m} / \mathrm{z}$ calcd. for $[\mathrm{M}+\mathrm{H}]^{+} \mathrm{C}_{53} \mathrm{H}_{91} \mathrm{I}_{2} \mathrm{O}_{9} \mathrm{P}_{4} \mathrm{Pt}_{2}$ 1639.2993, found $1639.3073 . \mathrm{m} / \mathrm{z}$ calcd. for $[\mathrm{M}+$ $\mathrm{Na}]^{+} \mathrm{C}_{53} \mathrm{H}_{90} \mathrm{I}_{2} \mathrm{NaO}_{9} \mathrm{P}_{4} \mathrm{Pt}_{2}$ 1661.2812, found 1661.2797.
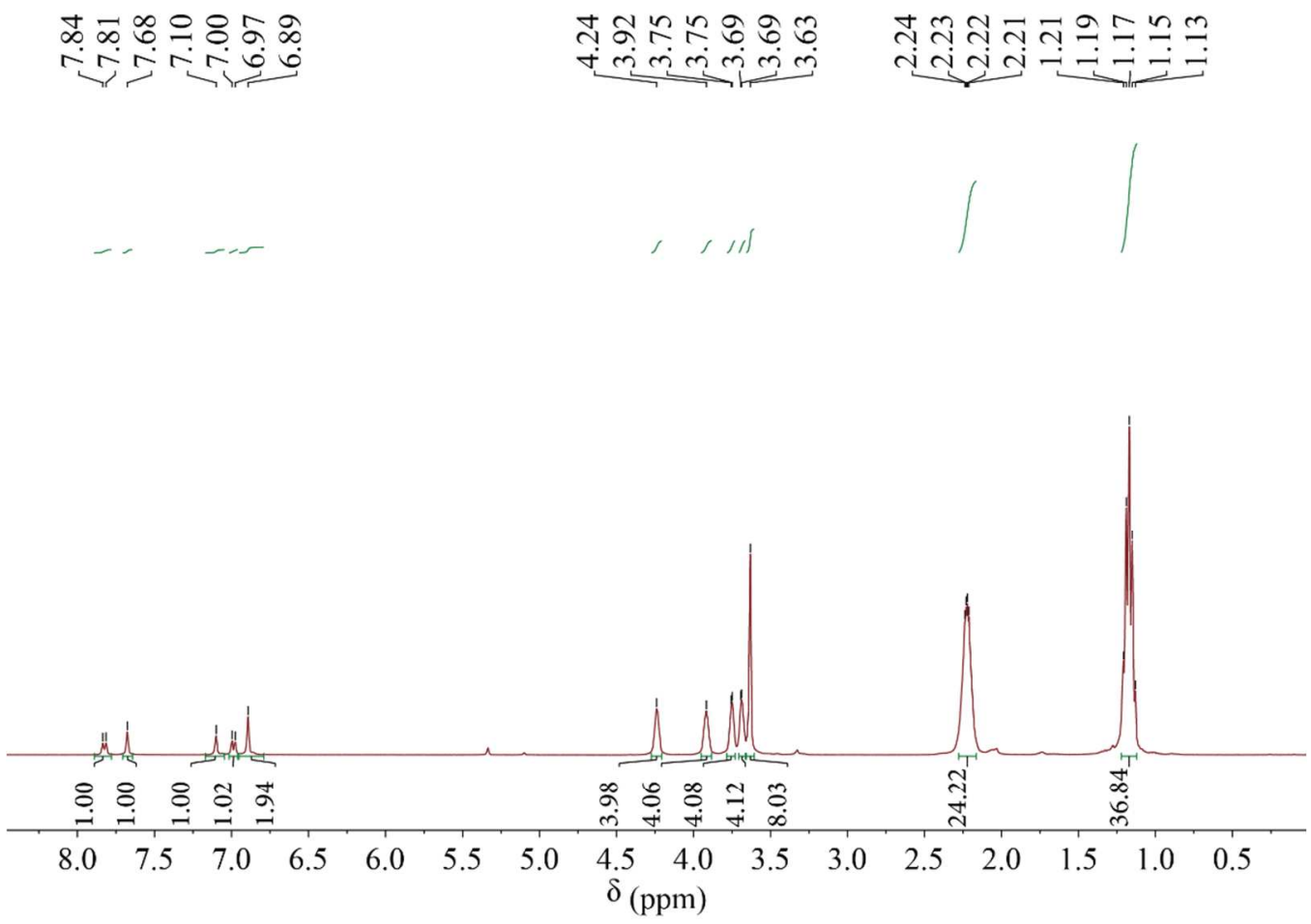

Figure S5. ${ }^{1} \mathrm{H}$ NMR spectrum (400 MHz, $\left.\mathrm{CD}_{2} \mathrm{Cl}_{2}, 298 \mathrm{~K}\right)$ of $\mathbf{S 3}$. 

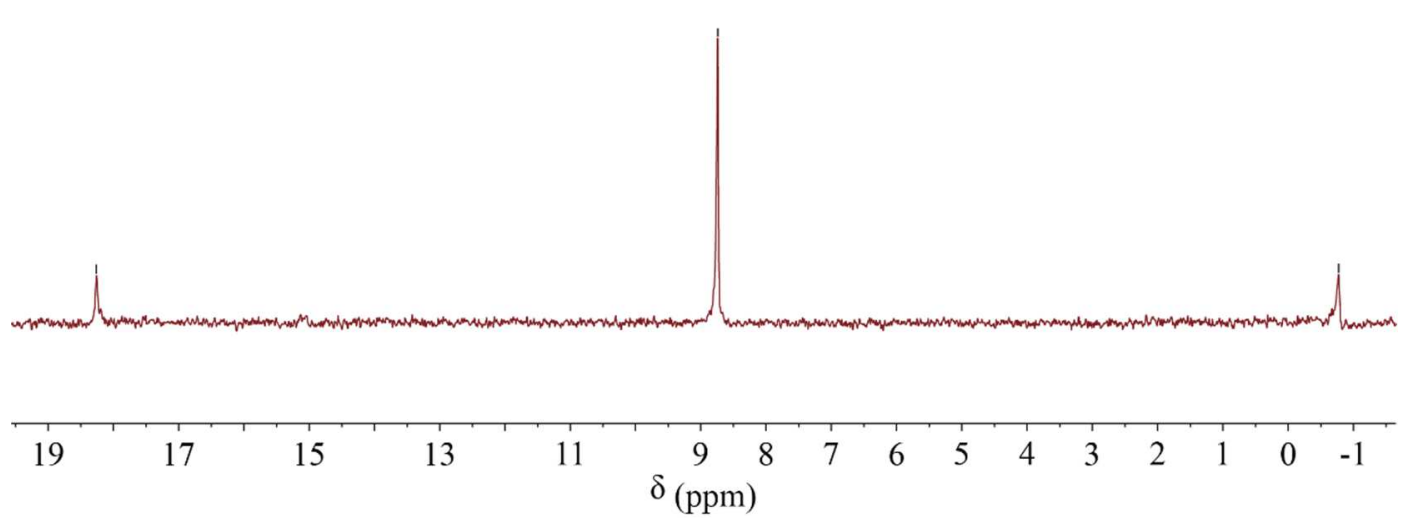

Figure S6. ${ }^{31} \mathrm{P}$ NMR spectrum $\left(121.4 \mathrm{MHz}, \mathrm{CD}_{2} \mathrm{Cl}_{2}, 298 \mathrm{~K}\right)$ of $\mathbf{S 3}$.

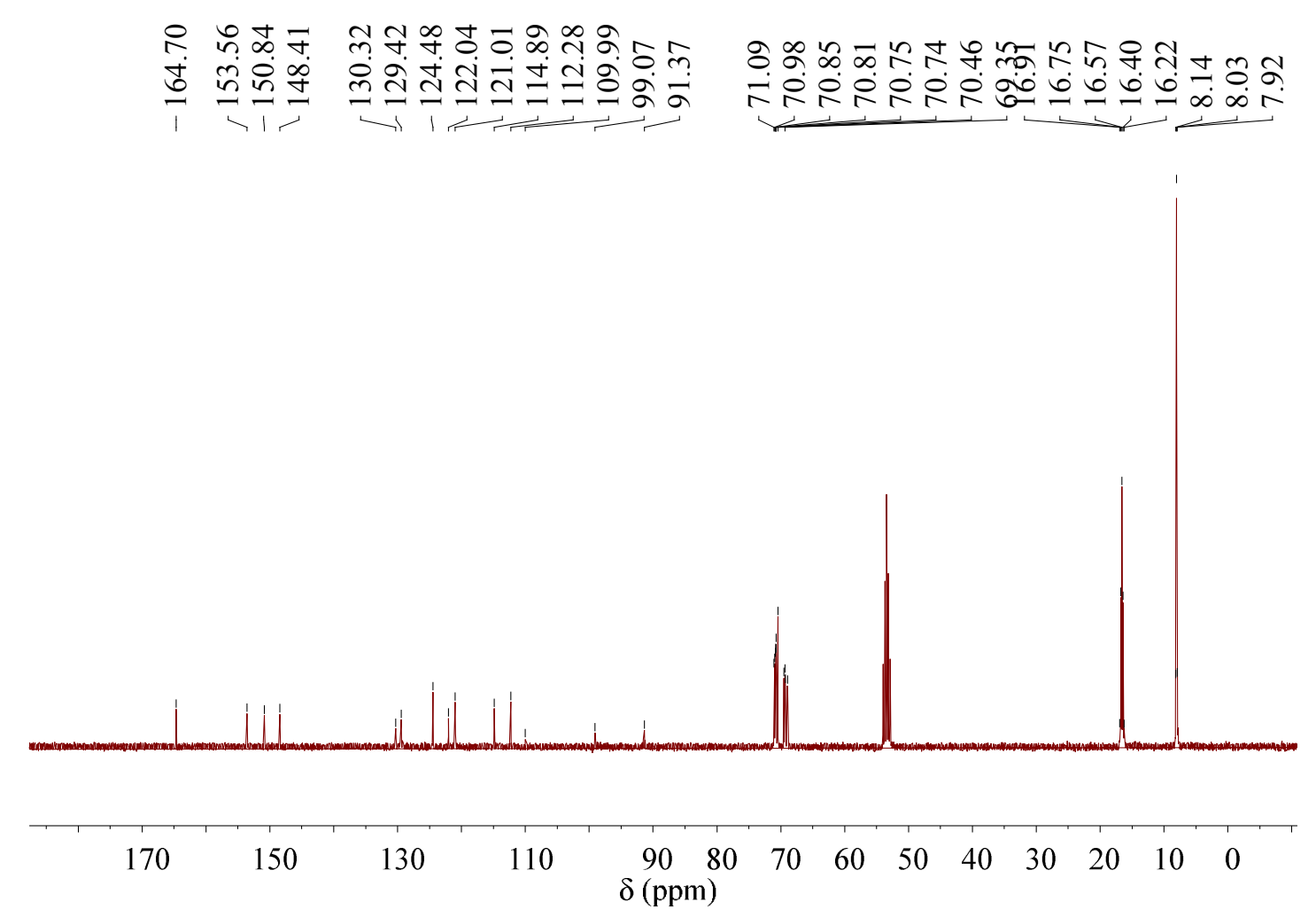

Figure S7. ${ }^{13} \mathrm{C}$ NMR spectrum (100 MHz, $\left.\mathrm{CD}_{2} \mathrm{Cl}_{2}, 298 \mathrm{~K}\right)$ of $\mathbf{S 3}$. 
Scheme S4. Synthesis of 2.

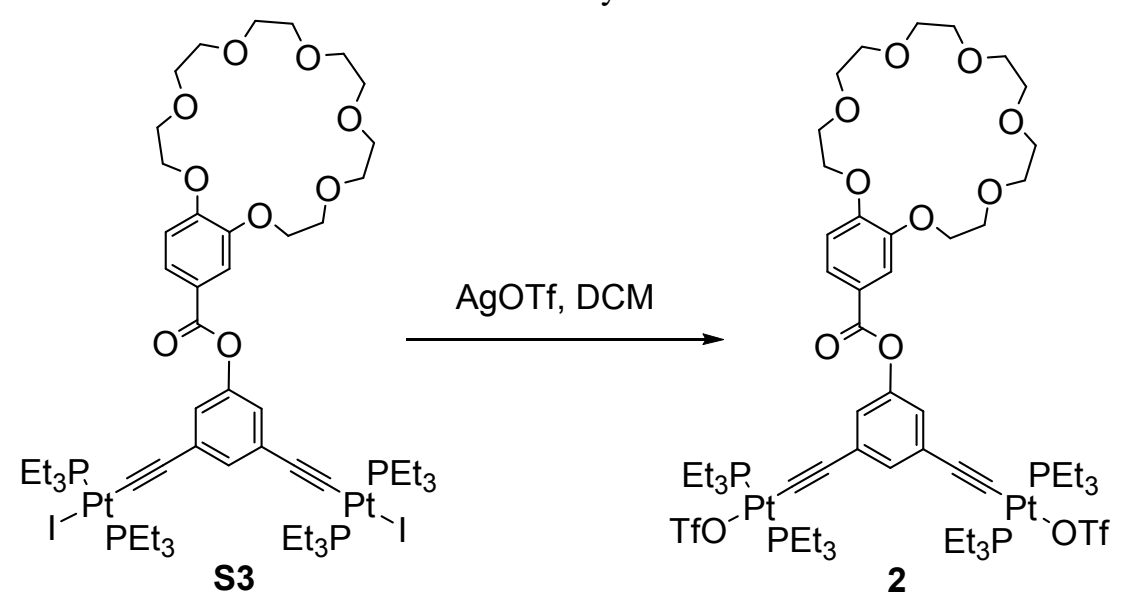

A $50 \mathrm{~mL}$ round-bottom Schlenk flask was charged with $82 \mathrm{mg}(0.05 \mathrm{mmol})$ of $\mathbf{S 3}$ and $10 \mathrm{~mL}$ of dichloromethane. To the solution was added $31 \mathrm{mg}(0.12 \mathrm{mmol})$ of AgOTf at once, resulting in a yellowish precipitate of AgI. After $4 \mathrm{~h}$ stirring at room temperature, the suspension was filtered through a glass fiber and the volume of the solution reduced to $5 \mathrm{~mL}$. Subsequent addition of diethyl ether resulted in the precipitation of the bistriflate salt $(75 \mathrm{mg}, 89 \%)$ as an off-white powder, $\mathrm{mp} 98$ $100{ }^{\circ} \mathrm{C}$. The ${ }^{1} \mathrm{H}$ NMR spectrum of 2 is shown in Figure S8. ${ }^{1} \mathrm{H}$ NMR (400 MHz, $\left.\mathrm{CD}_{2} \mathrm{Cl}_{2}, 298 \mathrm{~K}\right) \delta$ (ppm): $7.74(\mathrm{~d}, J=8.1 \mathrm{~Hz}, 1 \mathrm{H}), 7.58(\mathrm{~s}, 1 \mathrm{H}), 6.95-6.85(\mathrm{~m}, 2 \mathrm{H}), 6.80-6.71(\mathrm{~m}, 2 \mathrm{H}), 4.24-4.11(\mathrm{~m}, 4 \mathrm{H})$, 3.90-3.81 (m, 4H), 3.72-3.64 (m, 4H), 3.64-3.54 (m, 12H), 2.05-1.88 (m, 24H), 1.21-1.06 (m, 36H). The ${ }^{31} \mathrm{P}\left\{{ }^{1} \mathrm{H}\right\}$ NMR spectrum of $\mathbf{2}$ is shown in Figure S9. ${ }^{31} \mathrm{P}\left\{{ }^{1} \mathrm{H}\right\}$ NMR $\left(121.4 \mathrm{MHz}, \mathrm{CD}_{2} \mathrm{Cl}_{2}, 298 \mathrm{~K}\right)$ $\delta(\mathrm{ppm}): 21.90\left(\mathrm{~s},{ }^{1} J_{\mathrm{Pt}-\mathrm{P}}=2368.5 \mathrm{~Hz}\right)$. The ${ }^{13} \mathrm{C}$ NMR spectrum of 2 is shown in Figure S10. ${ }^{13} \mathrm{C}$ NMR $\left(100 \mathrm{MHz}, \mathrm{CD}_{2} \mathrm{Cl}_{2}, 298 \mathrm{~K}\right) \delta$ (ppm): 164.00, 153.49, 150.17, 147.99, 132.87, 125.70, 124.90, 123.88, $122.62,120.34,117.19,113.59,104.00,70.20,69.90,69.59,68.47,14.46$, and 7.57. HRESIMS: $\mathrm{m} / \mathrm{z}$ calcd. for $[\mathrm{M}-\mathrm{OTf}]^{+} \mathrm{C}_{54} \mathrm{H}_{90} \mathrm{~F}_{3} \mathrm{O}_{12} \mathrm{P}_{4} \mathrm{Pt}_{2} \mathrm{~S} 1533.4351$, found $1533.4580 ; \mathrm{m} / \mathrm{z}$ calcd. for $[\mathrm{M}-2 \mathrm{OTf}]^{2+}$ $\mathrm{C}_{53} \mathrm{H}_{90} \mathrm{O}_{9} \mathrm{P}_{4} \mathrm{Pt}_{2}$ 692.2410, found 692.2322. 


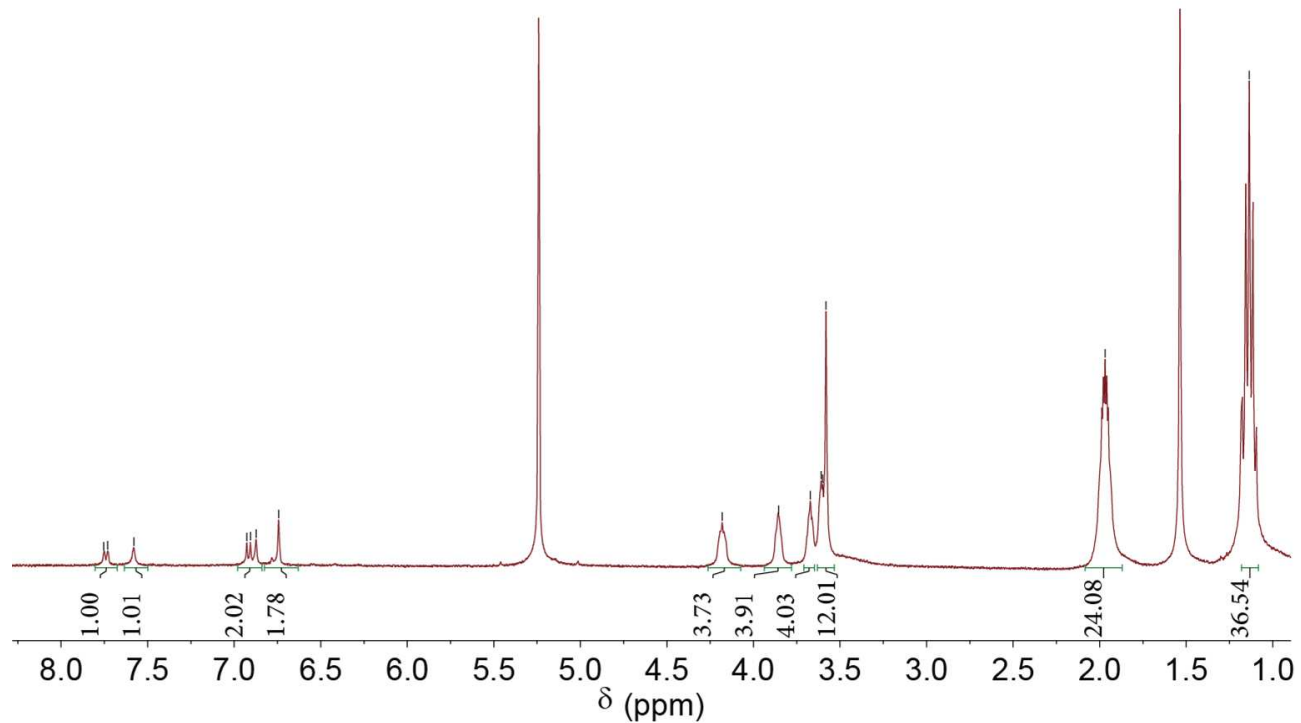

Figure S8. ${ }^{1} \mathrm{H}$ NMR spectrum (400 MHz, $\mathrm{CD}_{2} \mathrm{Cl}_{2}, 298 \mathrm{~K}$ ) of 2.

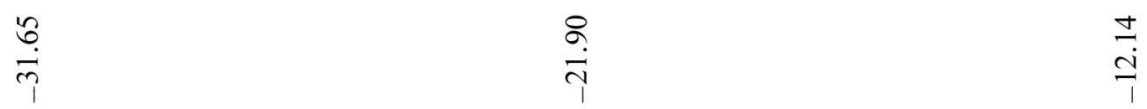

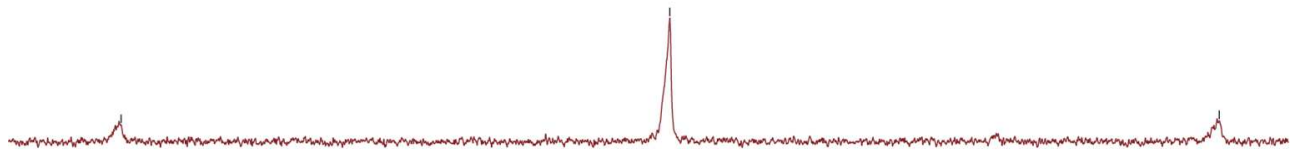

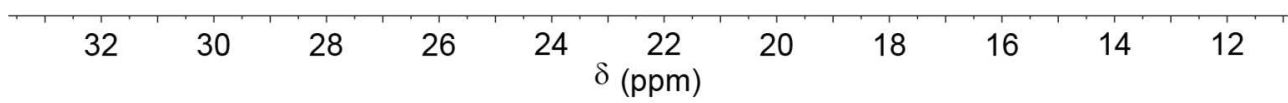

Figure S9. ${ }^{31} \mathrm{P}$ NMR spectrum (121.4 MHz, $\left.\mathrm{CD}_{2} \mathrm{Cl}_{2}, 298 \mathrm{~K}\right)$ of 2. 


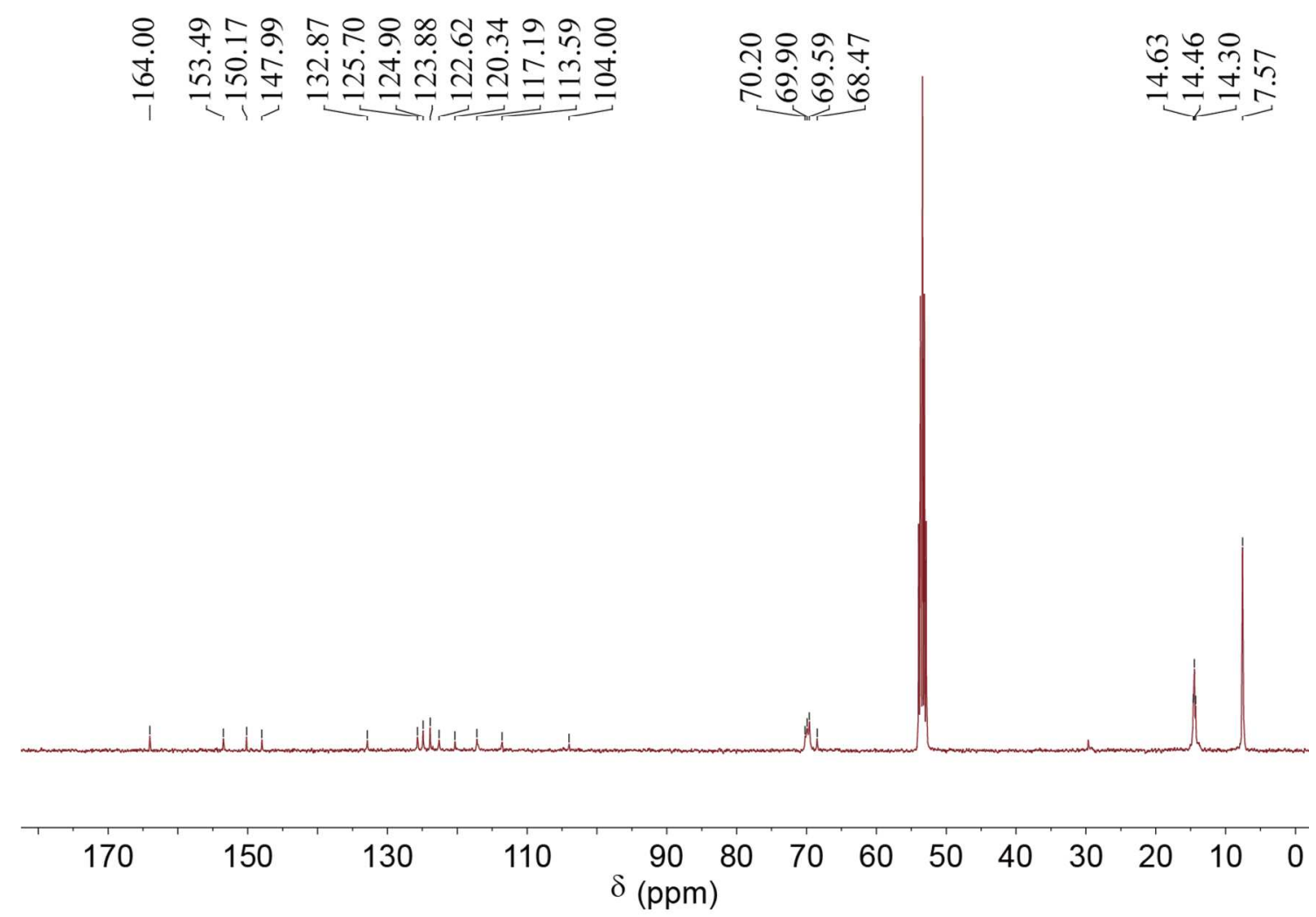

Figure S10. ${ }^{13} \mathrm{C}$ NMR spectrum (100 MHz, $\left.\mathrm{CD}_{2} \mathrm{Cl}_{2}, 298 \mathrm{~K}\right)$ of 2. 
Scheme S5. Synthesis of $\mathbf{1 .}$

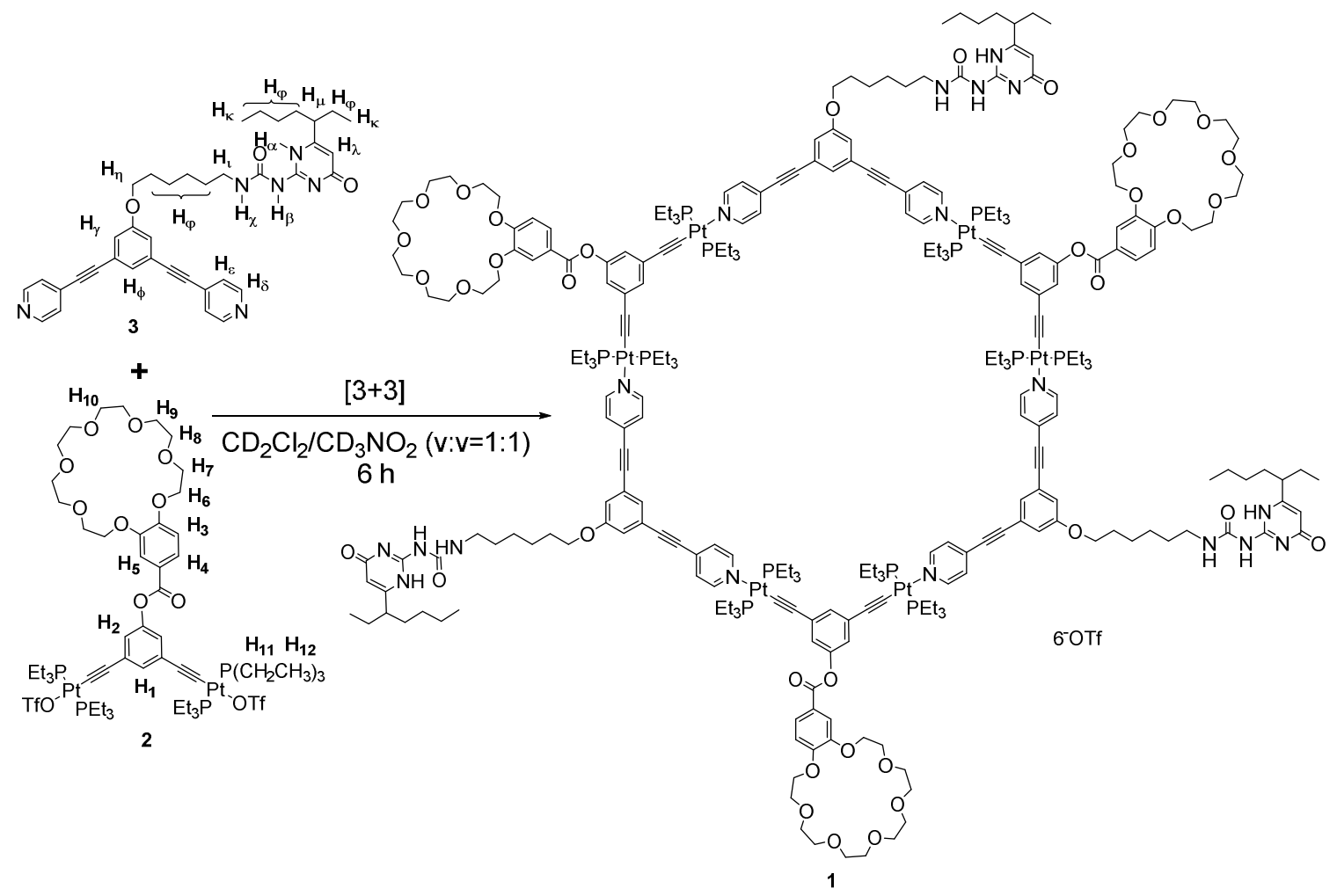

In a 1:1 molar ratio, $120^{\circ}$ UPy-functionalized donor $3(1.89 \mathrm{mg}, 0.003 \mathrm{mmol})$ and the $120^{\circ} \mathrm{B} 21 \mathrm{C} 7$ functionalized acceptor $2(5.05 \mathrm{mg}, 0.003 \mathrm{mmol})$ were dissolved in $1.0 \mathrm{~mL}$ of $\mathrm{CH}_{2} \mathrm{Cl}_{2} / \mathrm{CH}_{3} \mathrm{NO}_{2}$ $(v: v=1: 1)$ in a $2 \mathrm{~mL}$ glass vial. The reaction mixture was allowed to stir for $6 \mathrm{~h}$ at room temperature. To the resulting homogeneous solution, diethyl ether was added to precipitate the product, which was then isolated and dried under reduced pressure and re-dissolved in $\mathrm{CD}_{2} \mathrm{Cl}_{2} / \mathrm{CD}_{3} \mathrm{NO}_{2}$ (v:v=1:1) for characterization. The ${ }^{1} \mathrm{H}$ NMR spectrum of $\mathbf{1}$ is shown in Figure $\mathrm{S} 11 .{ }^{1} \mathrm{H}$ NMR (400 $\mathrm{MHz}, \mathrm{CD}_{2} \mathrm{Cl}_{2}$, $298 \mathrm{~K}) \delta(\mathrm{ppm}): 12.98-12.71(\mathrm{~m}, 6 \mathrm{H}), 10.19(\mathrm{~s}, 3 \mathrm{H}), 8.81-8.69(\mathrm{~m}, 12 \mathrm{H}), 7.87(\mathrm{~d}, J=8.6 \mathrm{~Hz}, 3 \mathrm{H})$, 7.86-7.79 (m, 12H), $7.72(\mathrm{~s}, 3 \mathrm{H}), 7.52(\mathrm{~s}, 3 \mathrm{H}), 7.32(\mathrm{~s}, 6 \mathrm{H}), 7.17(\mathrm{~s}, 3 \mathrm{H}), 7.12(\mathrm{~d}, J=8.6 \mathrm{~Hz}, 3 \mathrm{H})$, $7.03(\mathrm{~s}, 6 \mathrm{H}), 5.96(\mathrm{~s}, 3 \mathrm{H}), 4.18-4.12(\mathrm{~m}, 6 \mathrm{H}), 4.00-3.90(\mathrm{~m}, 12 \mathrm{H}), 3.79-3.72(\mathrm{~m}, 12 \mathrm{H}), 3.71-3.62(\mathrm{~m}$, $36 \mathrm{H}), 3.36-3.27(\mathrm{~m}, 6 \mathrm{H}), 2.51-2.43(\mathrm{~m}, 3 \mathrm{H}), 1.92-1.80(\mathrm{~m}, 72 \mathrm{H}), 1.70-1.47(\mathrm{~m}, 30 \mathrm{H}), 1.46-1.29(\mathrm{~m}$, $12 \mathrm{H}), 1.28-1.20(\mathrm{~m}, 108 \mathrm{H}), 0.98-0.85(\mathrm{~m}, 18 \mathrm{H})$. The ${ }^{31} \mathrm{P}\left\{{ }^{1} \mathrm{H}\right\}$ NMR spectrum of $\mathbf{1}$ is shown in Figure S12. ${ }^{31} \mathrm{P}\left\{{ }^{1} \mathrm{H}\right\}$ NMR $\left(121.4 \mathrm{MHz}, \mathrm{CD}_{2} \mathrm{Cl}_{2}, 298 \mathrm{~K}\right) \delta(\mathrm{ppm}): 14.28\left(\mathrm{~s},{ }^{1} J_{\mathrm{Pt}-\mathrm{P}}=2289.6 \mathrm{~Hz}\right)$. ESI-MS is shown in Figure S13: m/z $=1239.30[\mathrm{M}-5 \mathrm{OTf}]^{5+}$. 


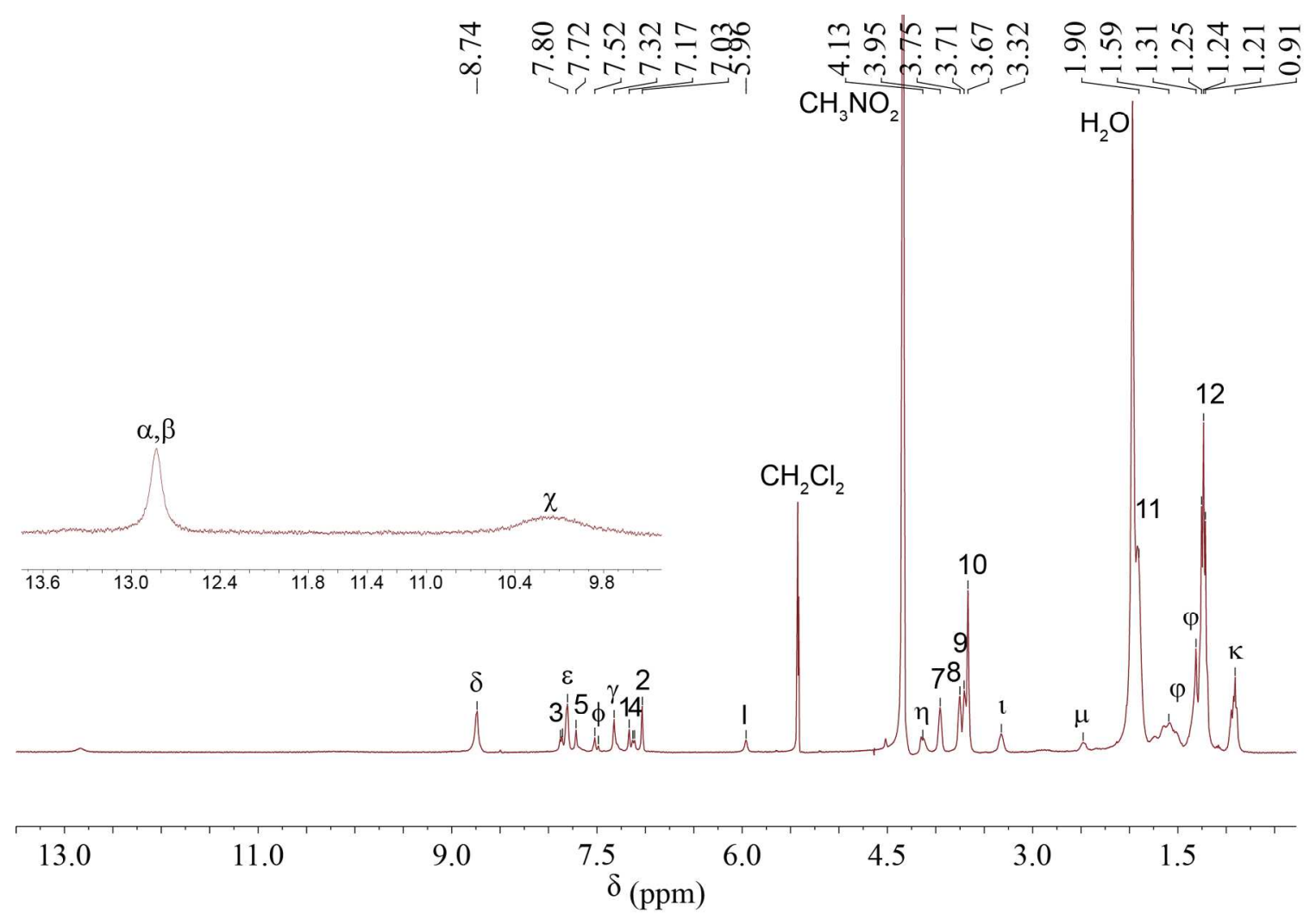

Figure S11. ${ }^{1} \mathrm{H}$ NMR spectrum $\left[400 \mathrm{MHz}, \mathrm{CD}_{2} \mathrm{Cl}_{2} / \mathrm{CD}_{3} \mathrm{NO}_{2}(1: 1\right.$ v/v), $298 \mathrm{~K}]$ of $\mathbf{1}$.

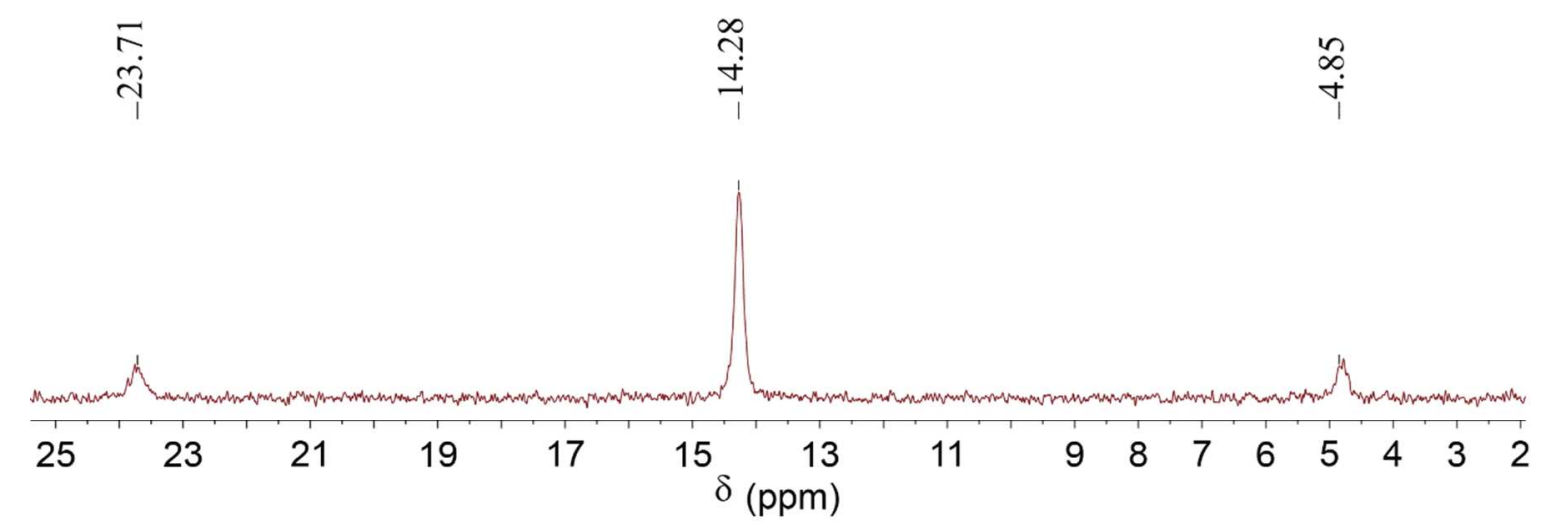

Figure S12. ${ }^{31} \mathrm{P}$ NMR spectrum [121.4 MHz, $\left.\mathrm{CD}_{2} \mathrm{Cl}_{2} / \mathrm{CD}_{3} \mathrm{NO}_{2}(1: 1 v / v), 298 \mathrm{~K}\right]$ of $\mathbf{1}$. 


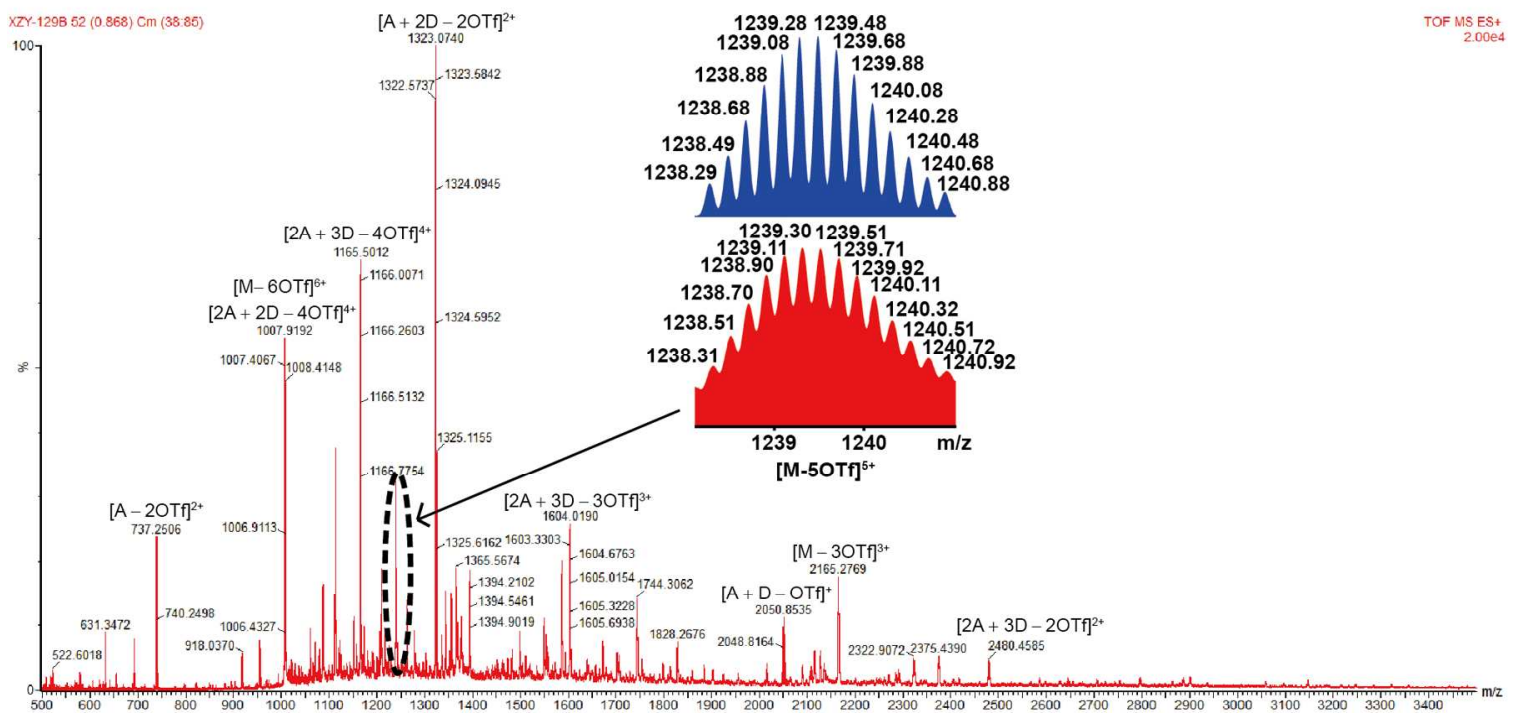

Figure S13. Experimental (red) and calculated (blue) electrospray ionization mass spectrum of 1 (A: acceptor 2, D: donor 3).

\subsection{Synthesis of crown ether functionalized hexagon 6}

Scheme S6. Synthesis of crown ether functionalized hexagon 6.
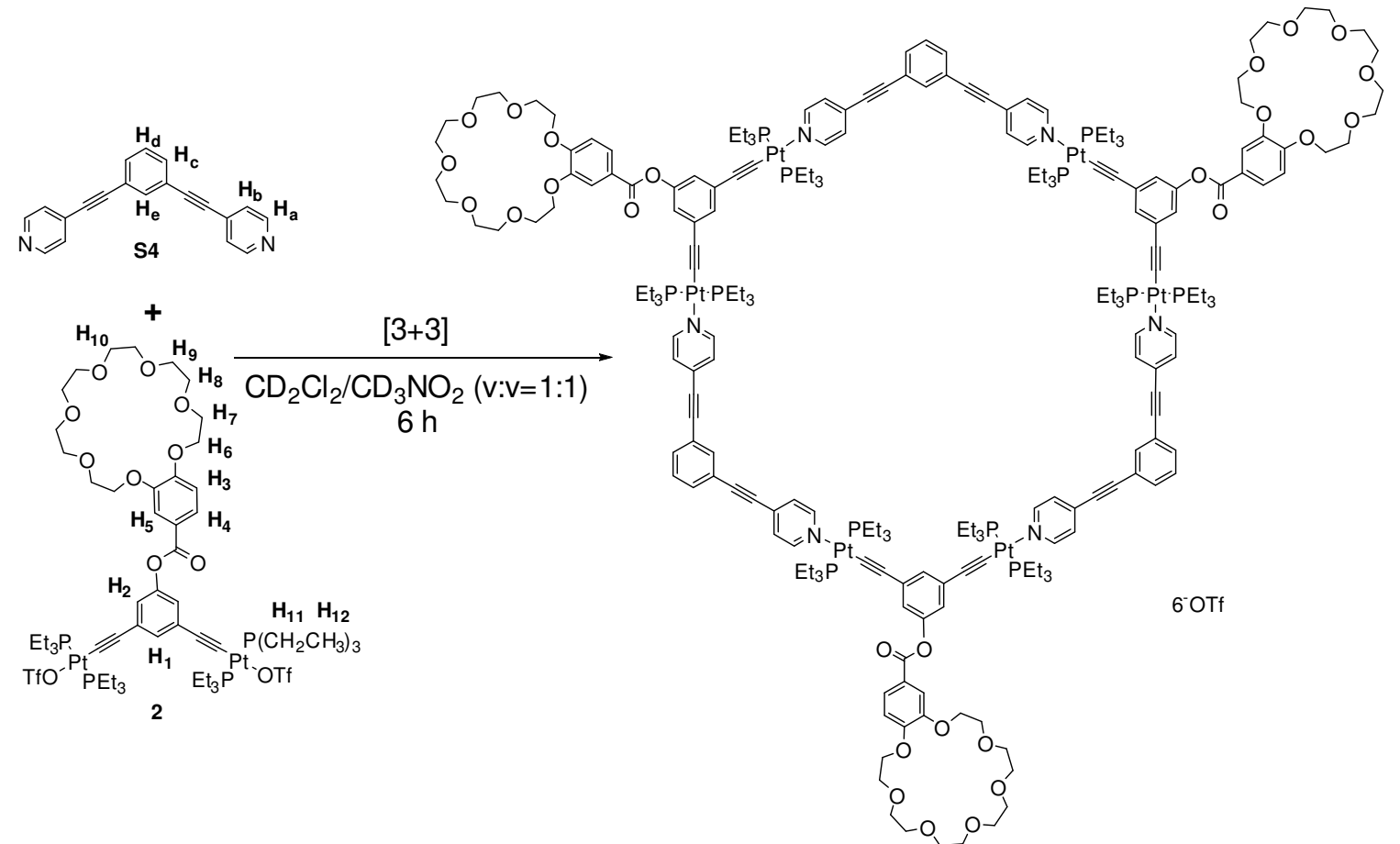

6

In a $1: 1$ molar ratio, $120^{\circ}$ donor $\mathbf{S} 4(0.84 \mathrm{mg}, 0.003 \mathrm{mmol})$ and the $120^{\circ} \mathrm{B} 21 \mathrm{C} 7$-functionalized acceptor $2(5.05 \mathrm{mg}, 0.003 \mathrm{mmol})$ were dissolved in $1.0 \mathrm{~mL}$ of $\mathrm{CH}_{2} \mathrm{Cl}_{2} / \mathrm{CH}_{3} \mathrm{NO}_{2}$ (v:v=1:1) in a $2 \mathrm{~mL}$ glass vial. The reaction mixture was allowed to stir for $6 \mathrm{~h}$ at room temperature. To the resulting homogeneous solution, diethyl ether was added to precipitate the product, which was then isolated and 
dried under reduced pressure and re-dissolved in $\mathrm{CD}_{2} \mathrm{Cl}_{2} / \mathrm{CD}_{3} \mathrm{NO}_{2}(v: v=1: 1)$ for characterization. The ${ }^{1} \mathrm{H}$ NMR spectrum of 6 is shown in Figure S14. ${ }^{1} \mathrm{H}$ NMR (400 MHz, $\left.\mathrm{CD}_{2} \mathrm{Cl}_{2}, 298 \mathrm{~K}\right) \delta(\mathrm{ppm}): 8.74$ (s, 12H), $7.87(\mathrm{~d}, J=8.6 \mathrm{~Hz}, 3 \mathrm{H}), 7.80(\mathrm{~s}, 12 \mathrm{H}), 7.72(\mathrm{~s}, 3 \mathrm{H}), 7.52(\mathrm{~s}, 3 \mathrm{H}), 7.32(\mathrm{~s}, 6 \mathrm{H}), 7.17(\mathrm{~s}, 3 \mathrm{H})$, $7.12(\mathrm{~d}, J=8.6 \mathrm{~Hz}, 3 \mathrm{H}), 7.03(\mathrm{~s}, 6 \mathrm{H}), 5.96(\mathrm{~s}, 3 \mathrm{H}), 4.18-4.12(\mathrm{~m}, 6 \mathrm{H}), 4.00-3.90$ (m, 12H), 3.79-3.72 (m, 12H), 3.71-3.62 (m, 36H), 3.36-3.27 (m, 6H), 2.51-2.43 (m, 3H), 1.92-1.80 (m, 72H), 1.70-1.47 $(\mathrm{m}, 30 \mathrm{H}), 1.46-1.29(\mathrm{~m}, 12 \mathrm{H}), 1.28-1.20(\mathrm{~m}, 108 \mathrm{H}), 0.98-0.85(\mathrm{~m}, 18 \mathrm{H})$. The ${ }^{31} \mathrm{P}\left\{{ }^{1} \mathrm{H}\right\}$ NMR spectrum of 6 is shown in Figure S15. ${ }^{31} \mathrm{P}\left\{{ }^{1} \mathrm{H}\right\} \mathrm{NMR}\left(121.4 \mathrm{MHz}, \mathrm{CD}_{2} \mathrm{Cl}_{2}, 298 \mathrm{~K}\right) \delta(\mathrm{ppm}): 15.19\left(\mathrm{~s},{ }^{1} J_{\mathrm{Pt}-\mathrm{P}}=\right.$ $2245.9 \mathrm{~Hz})$. ESI-TOF-MS is shown in Figure S16: $\mathrm{m} / \mathrm{z}=1371.68[\mathrm{M}-3 \mathrm{OTf}+\mathrm{K}]^{4+}$.

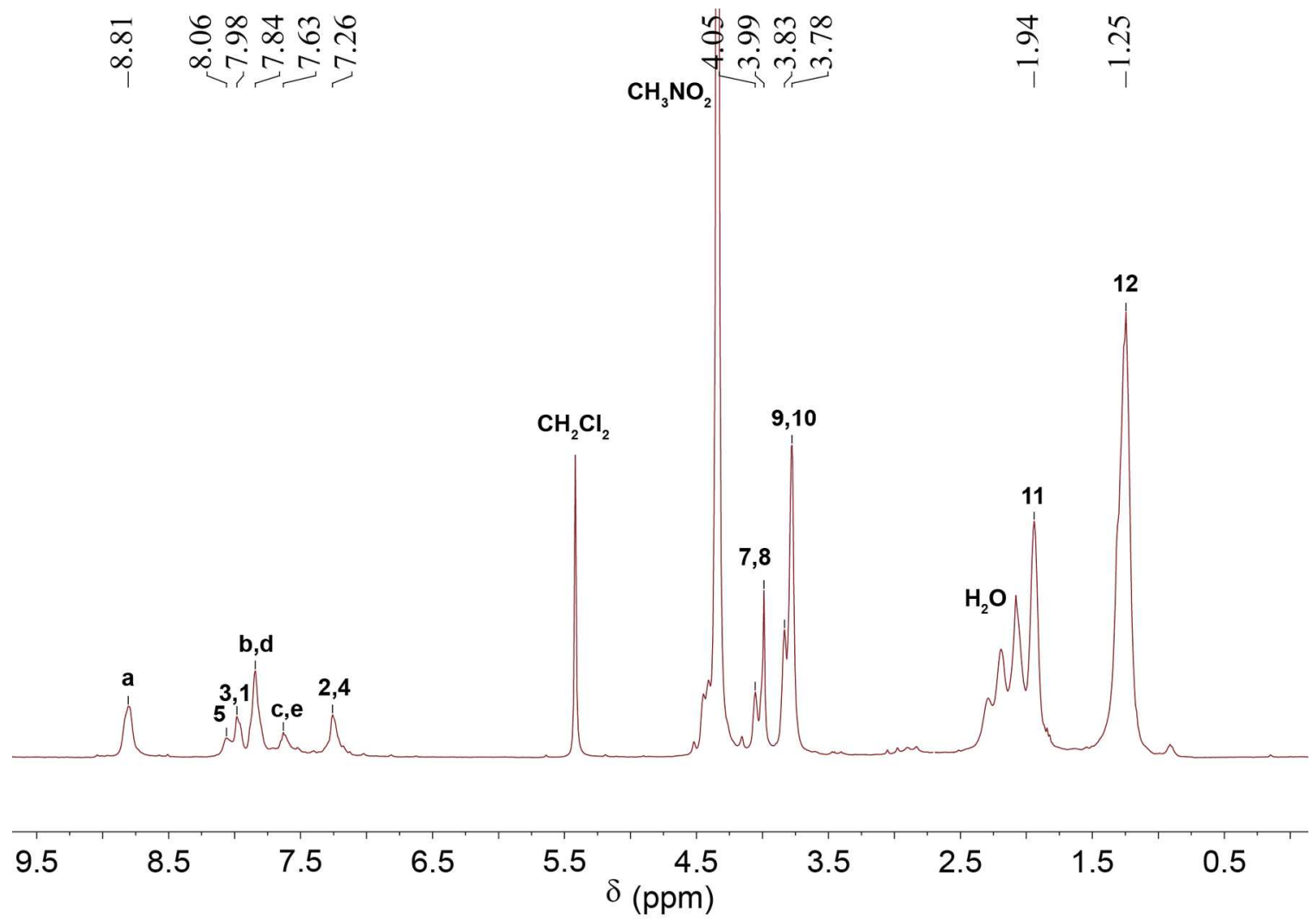

Figure S14. ${ }^{1} \mathrm{H}$ NMR spectrum $\left[400 \mathrm{MHz}, \mathrm{CD}_{2} \mathrm{Cl}_{2} / \mathrm{CD}_{3} \mathrm{NO}_{2}(1: 1 \mathrm{v} / \mathrm{v}), 298 \mathrm{~K}\right]$ of 6. 


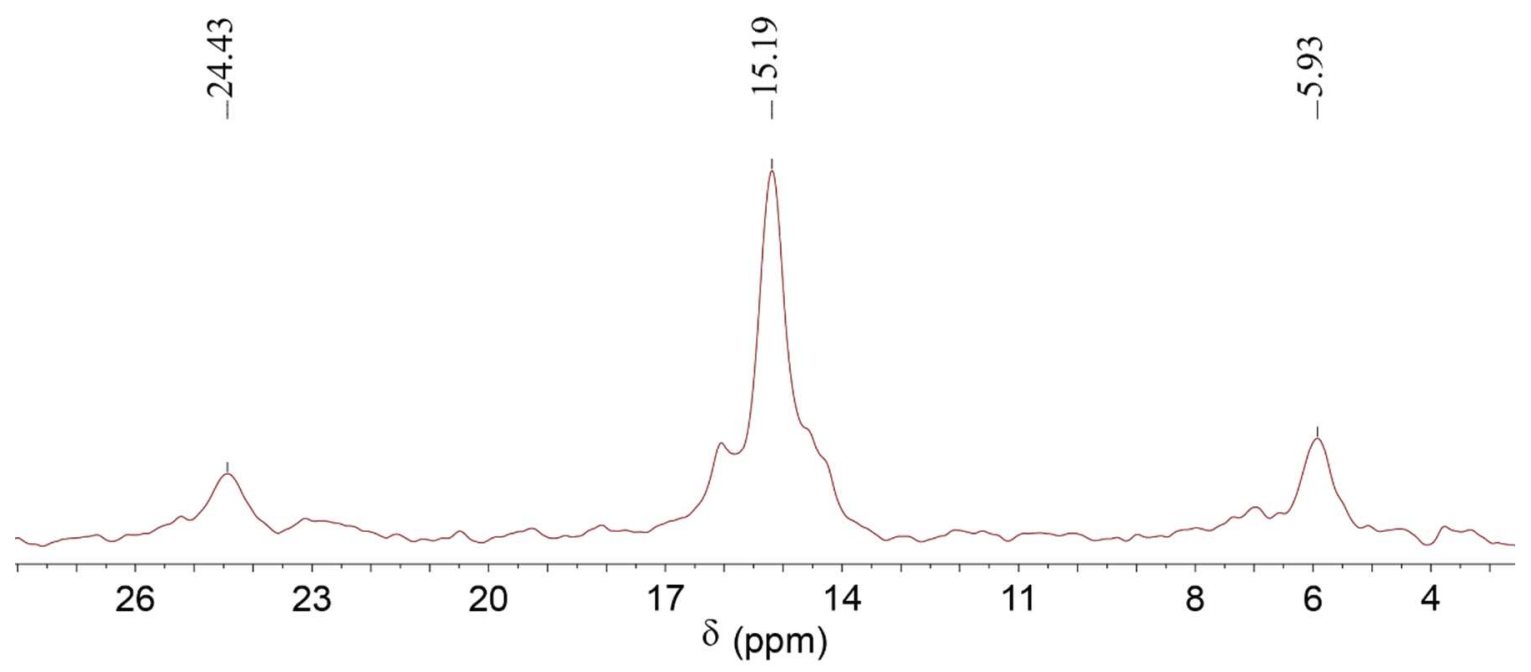

Figure S15. ${ }^{31} \mathrm{P}$ NMR spectrum [121.4 MHz, $\left.\mathrm{CD}_{2} \mathrm{Cl}_{2} / \mathrm{CD}_{3} \mathrm{NO}_{2}(1: 1 v / v), 298 \mathrm{~K}\right]$ of 6.

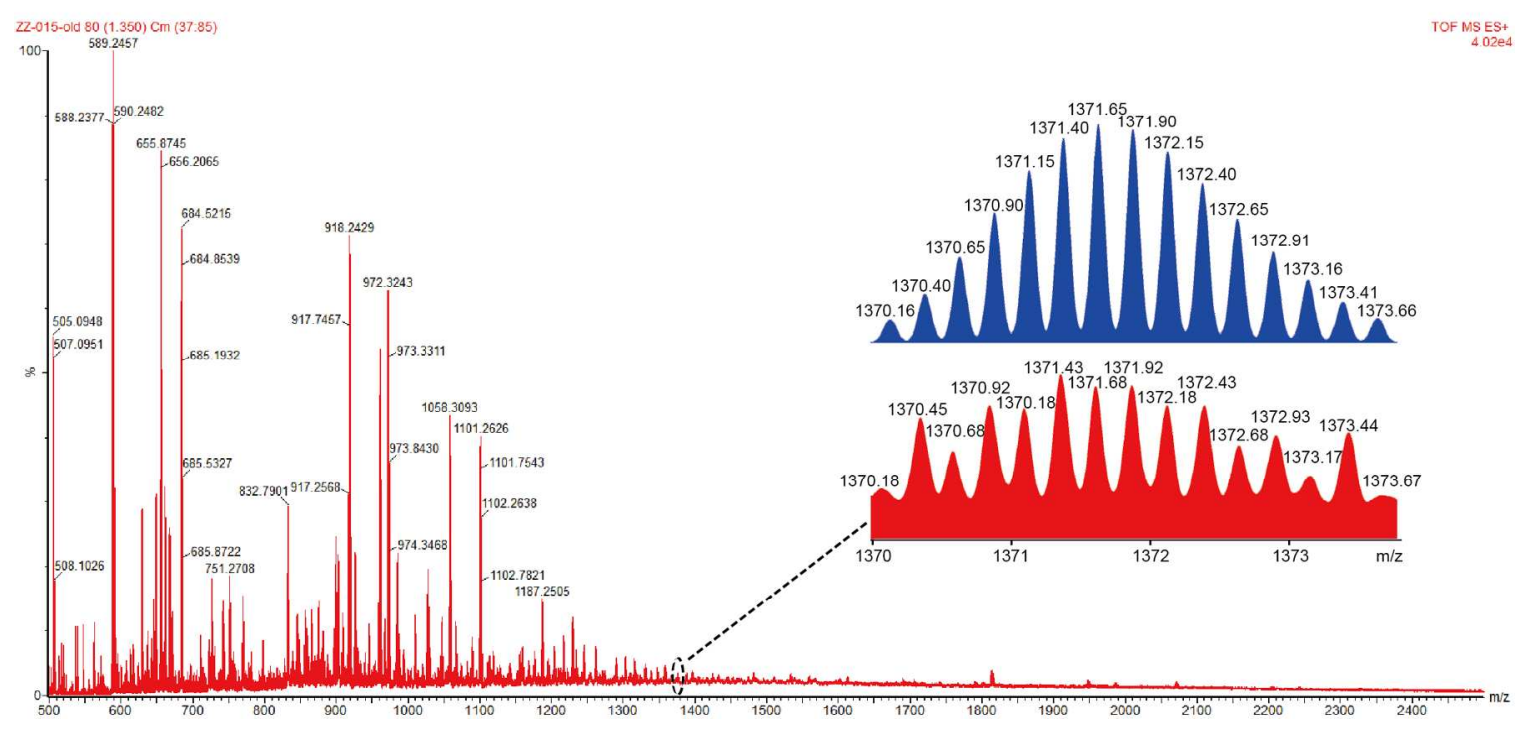

Figure S16. Experimental (red) and calculated (blue) electrospray ionization mass spectrum of 6. 
3. Comparison of ${ }^{1} \mathrm{H}$ NMR spectra of network 1 in $\mathrm{CD}_{2} \mathrm{Cl}_{2} / \mathrm{CD}_{3} \mathrm{NO}_{2}(1: 1 \mathrm{v} / \mathrm{v})$ and DMSO-d $\mathrm{d}_{6}$

(a)

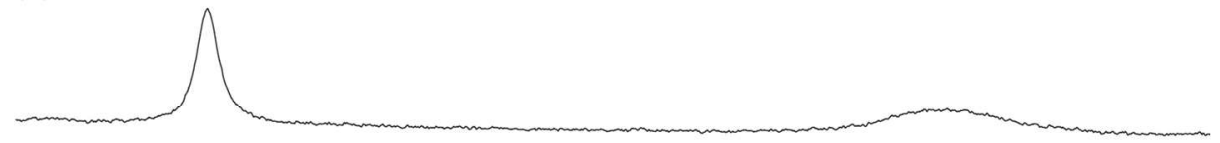

(b)

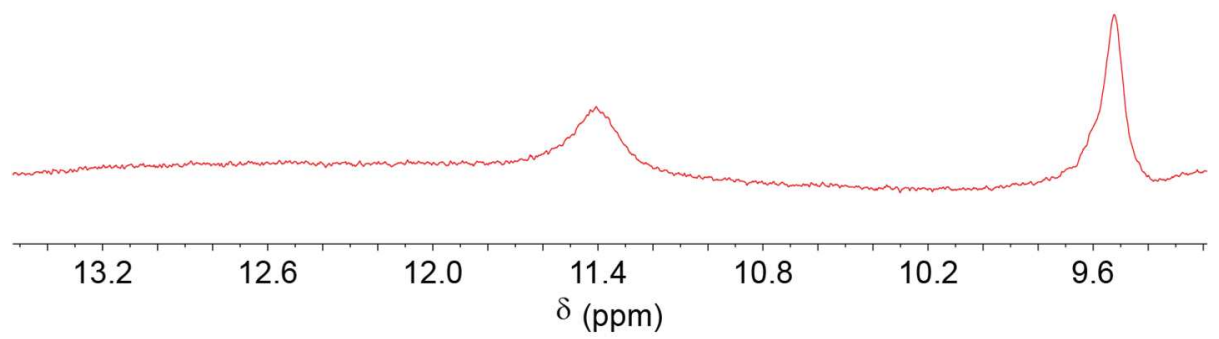

Figure S17. Partial ${ }^{1} \mathrm{H}$ NMR spectra of network 1 (400 MHz, $298 \mathrm{~K}$ ) in different solutions: (a) $\mathrm{CD}_{2} \mathrm{Cl}_{2} / \mathrm{CD}_{3} \mathrm{NO}_{2}(1: 1 v / v)$; (b) DMSO- $d_{6}$.

4. DOSY NMR experiments of crown ether functionalized hexagon $\mathbf{6}$ and supramolecular network $\mathbf{1}$ at $10.0 \mathrm{mM}$.

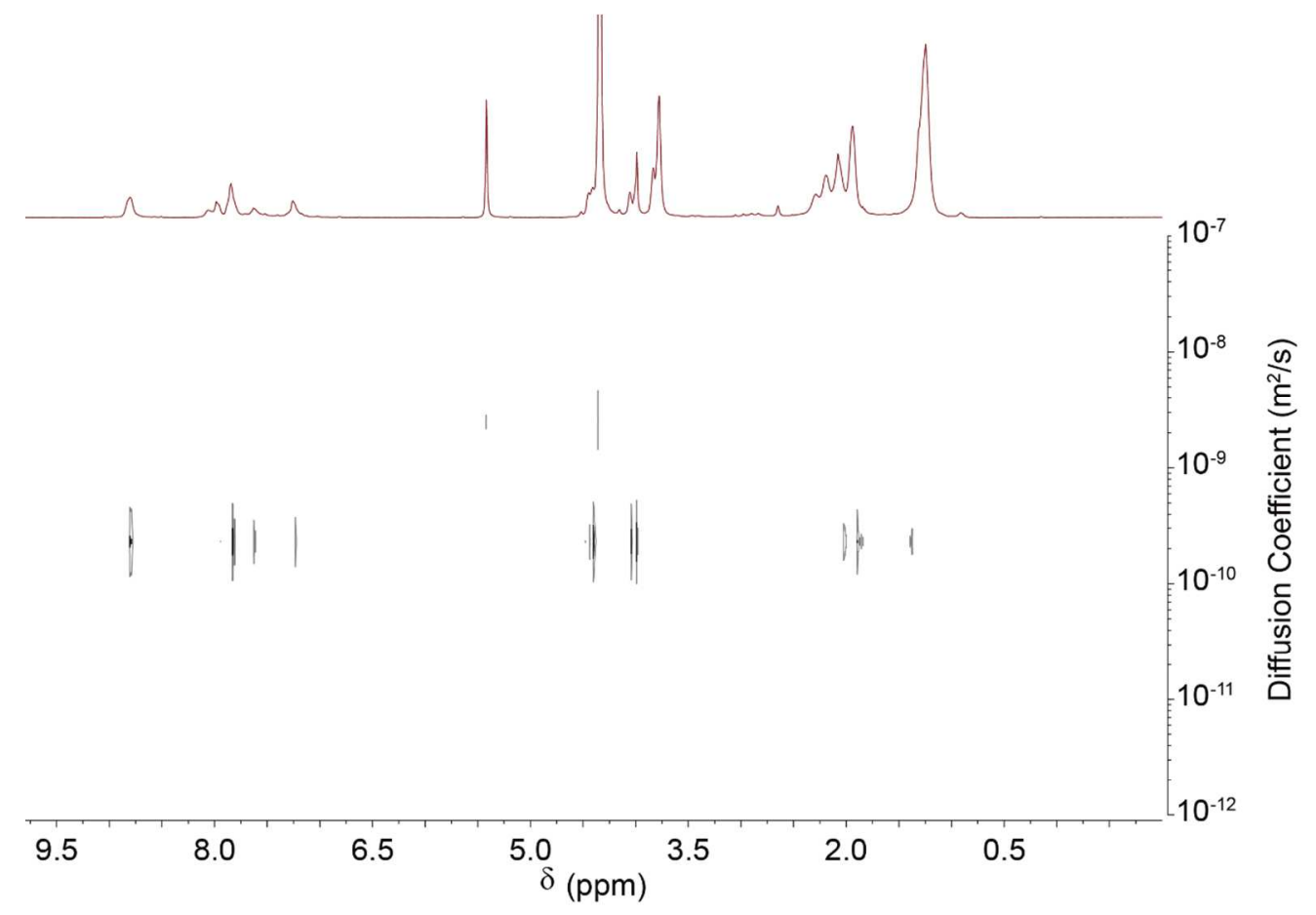

Figure S18. DOSY NMR spectrum $\left[\mathrm{CD}_{2} \mathrm{Cl}_{2} / \mathrm{CD}_{3} \mathrm{NO}_{2}(1: 1 \mathrm{v} / v), 298 \mathrm{~K}, 500 \mathrm{MHz}\right]$ of 6 at $10.0 \mathrm{mM}$. 


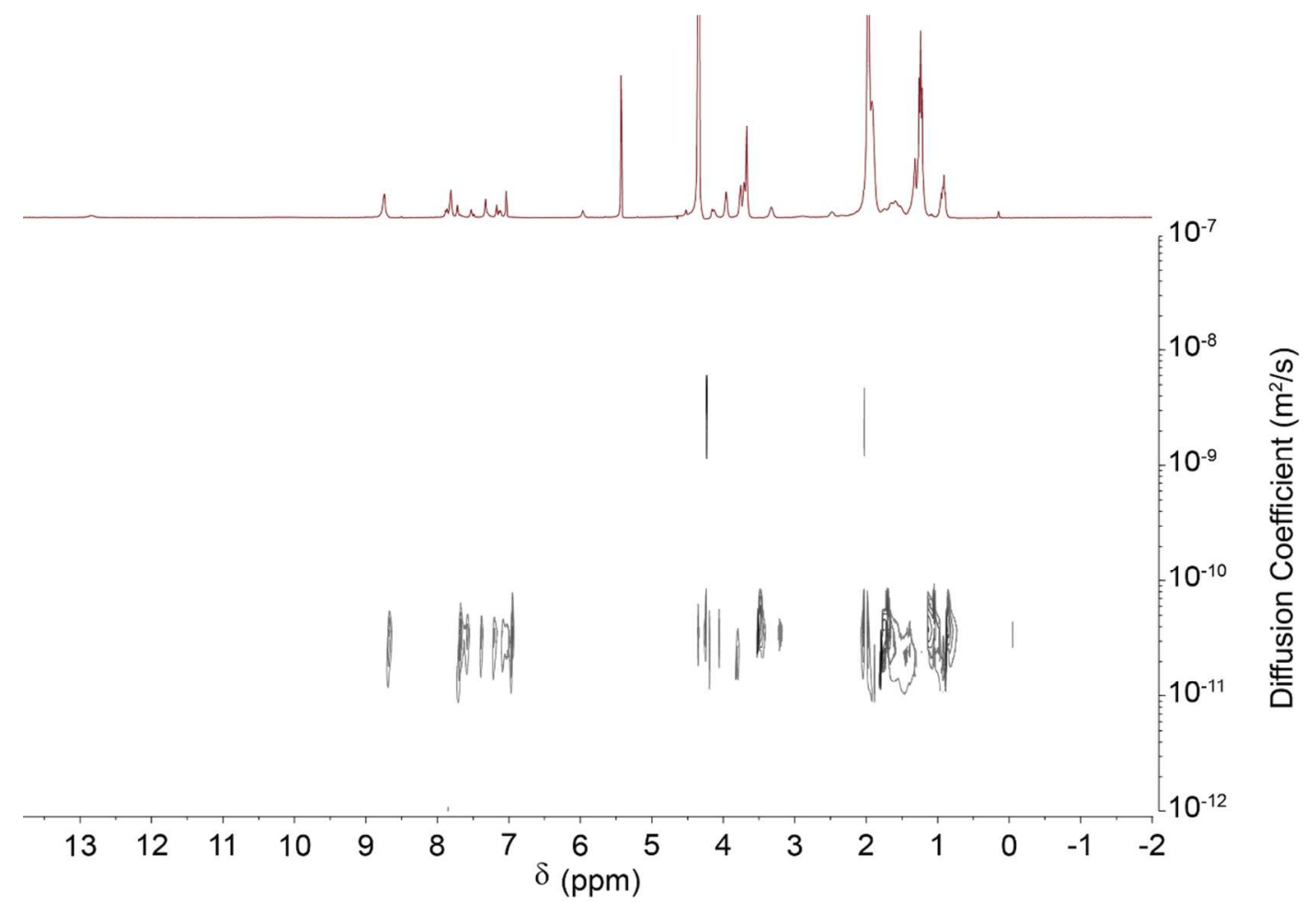

Figure S19. DOSY NMR spectrum $\left[\mathrm{CD}_{2} \mathrm{Cl}_{2} / \mathrm{CD}_{3} \mathrm{NO}_{2}(1: 1 \mathrm{v} / v), 298 \mathrm{~K}, 500 \mathrm{MHz}\right]$ of 1 at $10.0 \mathrm{mM}$.

\section{Absorption and emission spectra of functionalized complexes}

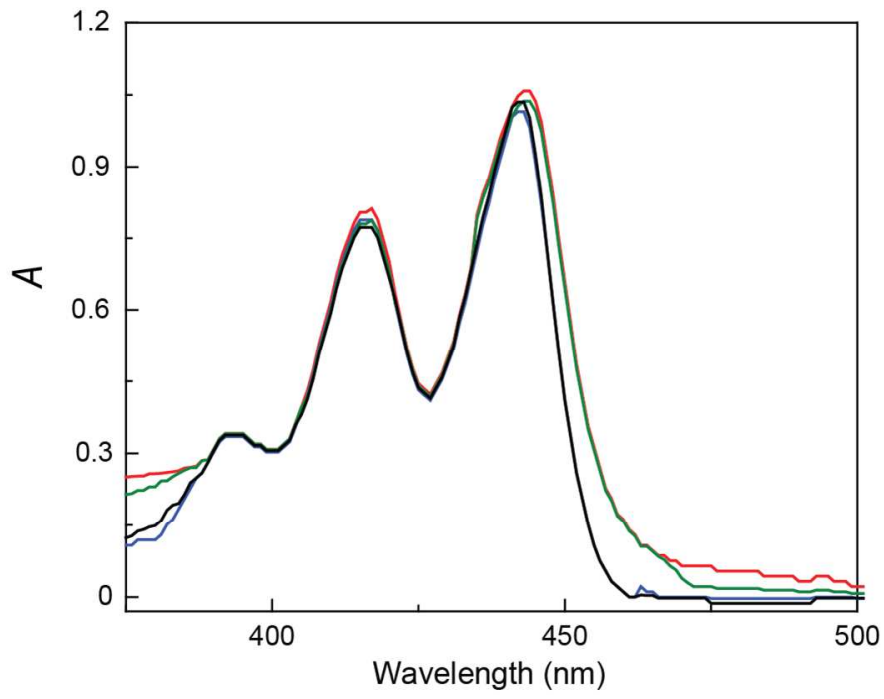

Figure S20. Absorption spectra of free 4a (blue), functional network 5a (red), 3つ4a (black), and functionalized hexagon $\mathbf{6}(\mathbf{4 a})_{3}$ (green) $(c=30.0 \mu \mathrm{M}$ based on the ammonium salt units) in dichloromethane. 


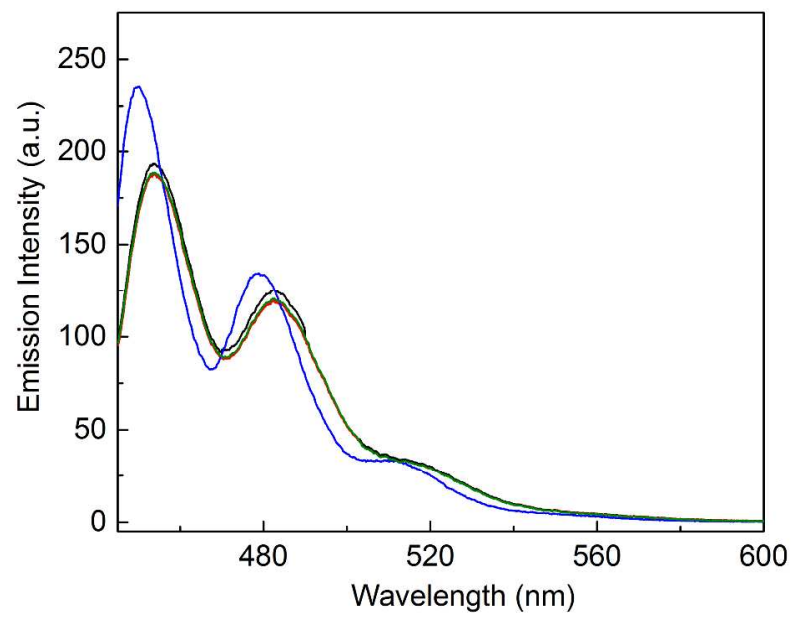

Figure S21. Fluorescence spectra of free 4a (blue), functional network 5a (red), 3つ4a (black), and functionalized hexagon 6 (4a) ${ }_{3}$ (green) $\left(c=30.0 \mu \mathrm{M}\right.$ based on the ammonium salt units, $\left.\lambda_{\mathrm{ex}}=441 \mathrm{~nm}\right)$ in dichloromethane. 


\section{Complexation studies of host/guest interactions using proton NMR}

The B21C7 host can form a more stable 1:1 complex with $\mathrm{K}^{+}$, which results in the decomplexation between the B21C7 unit and the dialkylammonium moiety. 18-crown-6 (18C6) can form a more stable 1:1 complex with $\mathrm{K}^{+}$relative to $\mathrm{B} 21 \mathrm{C}$, which can be used to extract $\mathrm{K}^{+}$from B21C7 moiety. Therefore, the functionalization can be modulated by adding and removing $\mathrm{K}^{+}$, and these reversible transitions can be monitored by ${ }^{1} \mathrm{H}$ NMR experiments. Addition of dialkylammoniumto the solution of hosts result in splitting of signals into two sets, corresponding to the complexed and uncomplexed species, due to the slow-exchange nature of the complexation reaction. The addition of $\mathrm{KPF}_{6}$ to the mixtures of hosts and ammonium salts results in remarkable changes of the proton chemical shifts, indicating that the complexation between B21C7 and dialkylammonium salt was essentially quenched. After $18 \mathrm{C} 6$ was added to this solution, thecomplexation between B21C7 moiety and dialkylammonium salt was recovered and the complicated signals were observed again.

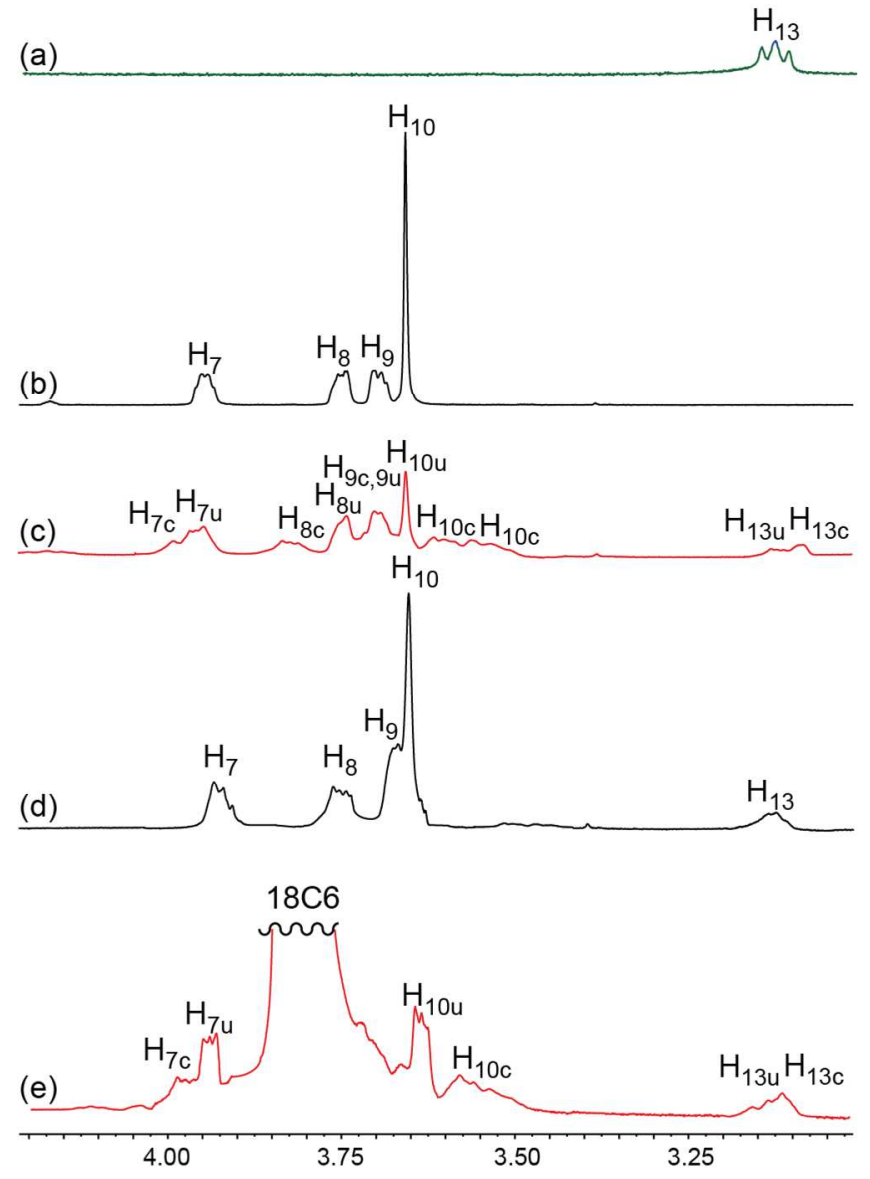

Figure S22. Partial ${ }^{1} \mathrm{H}$ NMR spectra $\left[400 \mathrm{MHz}, \mathrm{CD}_{2} \mathrm{Cl}_{2} / \mathrm{CD}_{3} \mathrm{NO}_{2}(1: 1, v / v), 298 \mathrm{~K}\right]$ of (a) dialkylammonium salt 4a; (b) acceptor 2; (c) 2つ4a; (d) after addition of 1.5 equiv. of $\mathrm{KPF}_{6}$ to (c); and (e) after addition of 1.5 equiv. of $18 \mathrm{C} 6$ to (d). Here "c" and "u" denote complexed and uncomplexed moieties, respectively. 

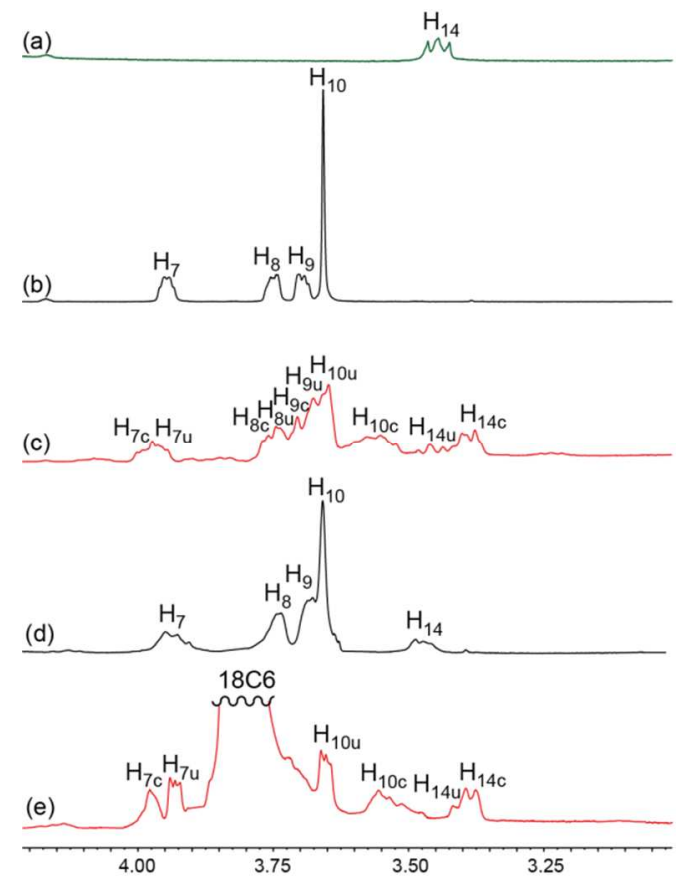

Figure S23. Partial ${ }^{1} \mathrm{H}$ NMR spectra $\left[400 \mathrm{MHz}, \mathrm{CD}_{2} \mathrm{Cl}_{2} / \mathrm{CD}_{3} \mathrm{NO}_{2}(1: 1, v / v), 298 \mathrm{~K}\right]$ of (a) dialkylammonium salt $\mathbf{4 b}$; (b) acceptor $\mathbf{2}$; (c) $\mathbf{2} \supset \mathbf{4 b}$; (d) after addition of 1.5 equiv. of $\mathrm{KPF}_{6}$ to (c); and (e) after addition of 1.5 equiv. of $18 \mathrm{C} 6$ to (d). Here "c" and " $\mathrm{u}$ " denote complexed and uncomplexed moieties, respectively.
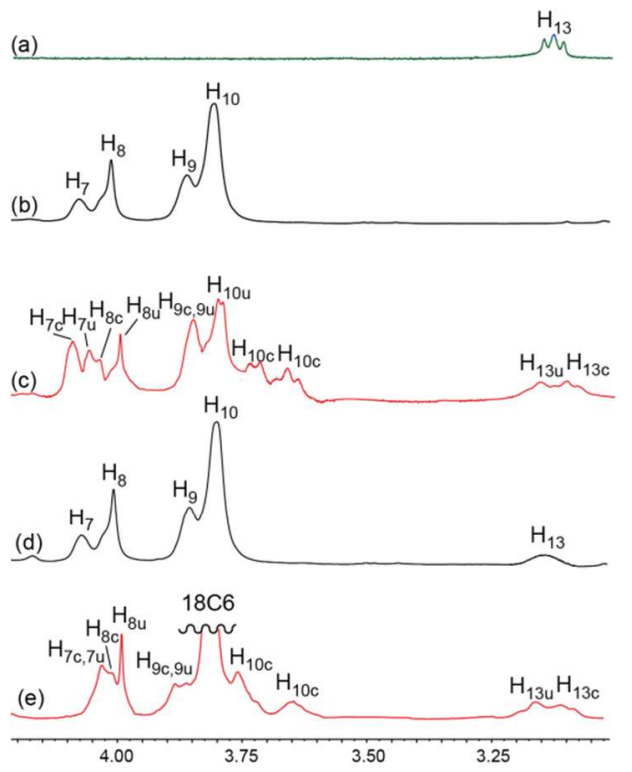

Figure S24. Partial ${ }^{1} \mathrm{H}$ NMR spectra $\left[400 \mathrm{MHz}, \mathrm{CD}_{2} \mathrm{Cl}_{2} / \mathrm{CD}_{3} \mathrm{NO}_{2}(1: 1, v / v), 298 \mathrm{~K}\right]$ of (a) dialkylammonium salt 4a; (b) 6; (c) $\mathbf{6}(\mathbf{4 a})_{3}$; (d) after addition of 1.5 equiv. of $\mathrm{KPF}_{6}$ to (c); and (e) after addition of 1.5 equiv. of $18 \mathrm{C} 6$ to (d). Here "c" and " $u$ " denote complexed and uncomplexed moieties, respectively. 

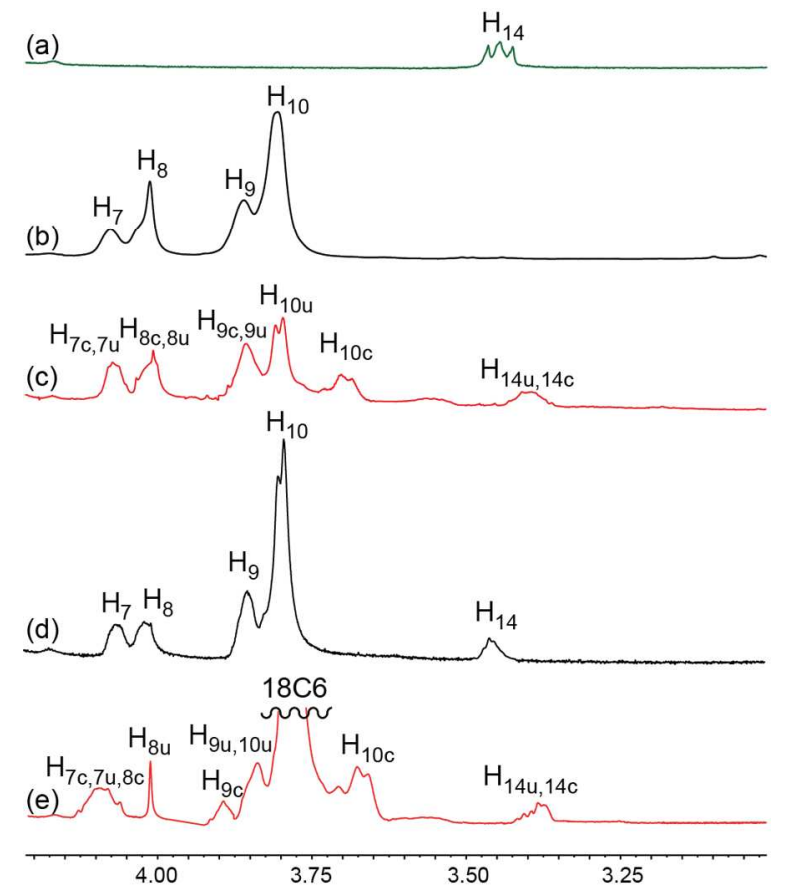

Figure S25. Partial ${ }^{1} \mathrm{H}$ NMR spectra $\left[400 \mathrm{MHz}, \mathrm{CD}_{2} \mathrm{Cl}_{2} / \mathrm{CD}_{3} \mathrm{NO}_{2}(1: 1, v / v), 298 \mathrm{~K}\right]$ of (a) dialkylammonium salt $4 \mathbf{b}$; (b) 6 ; (c) $\mathbf{6} \supset(\mathbf{4 b})_{3}$; (d) after addition of 1.5 equiv. of $\mathrm{KPF}_{6}$ to (c); and (e) after addition of 1.5 equiv. of $18 \mathrm{C} 6$ to (d). Here "c" and "u" denote complexed and uncomplexed moieties, respectively.

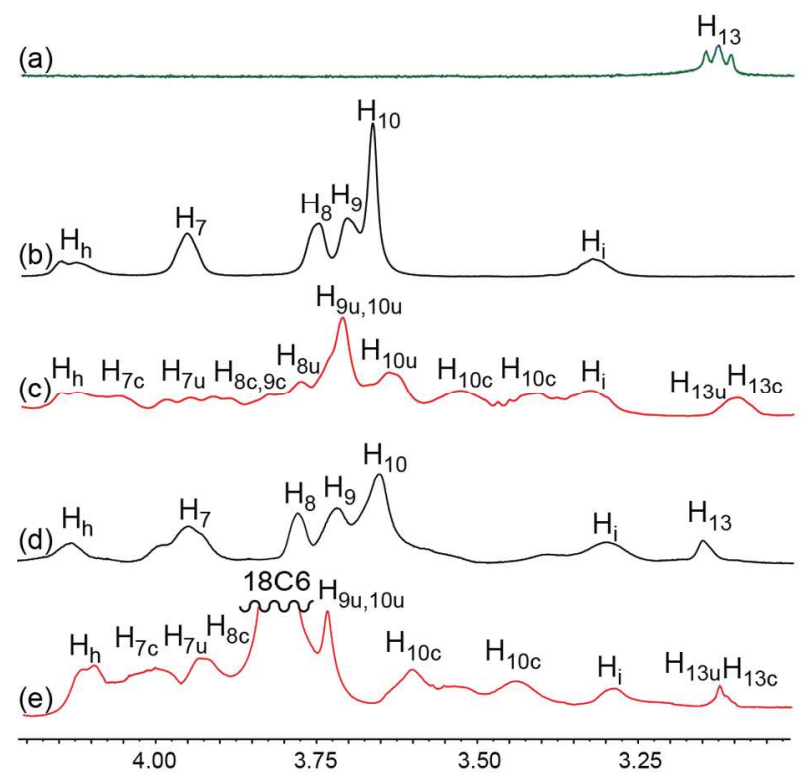

Figure S26. Partial ${ }^{1} \mathrm{H}$ NMR spectra $\left[400 \mathrm{MHz}, \mathrm{CD}_{2} \mathrm{Cl}_{2} / \mathrm{CD}_{3} \mathrm{NO}_{2}(1: 1, v / v), 298 \mathrm{~K}\right]$ of (a) dialkylammonium salt 4a; (b) $\mathbf{1}$; (c) $\mathbf{5 a}$; (d) after addition of 1.5 equiv. of $\mathrm{KPF}_{6}$ to (c); and (e) after addition of 1.5 equiv. of $18 \mathrm{C} 6$ to (d). Here "c" and "u" denote complexed and uncomplexed moieties, respectively. 

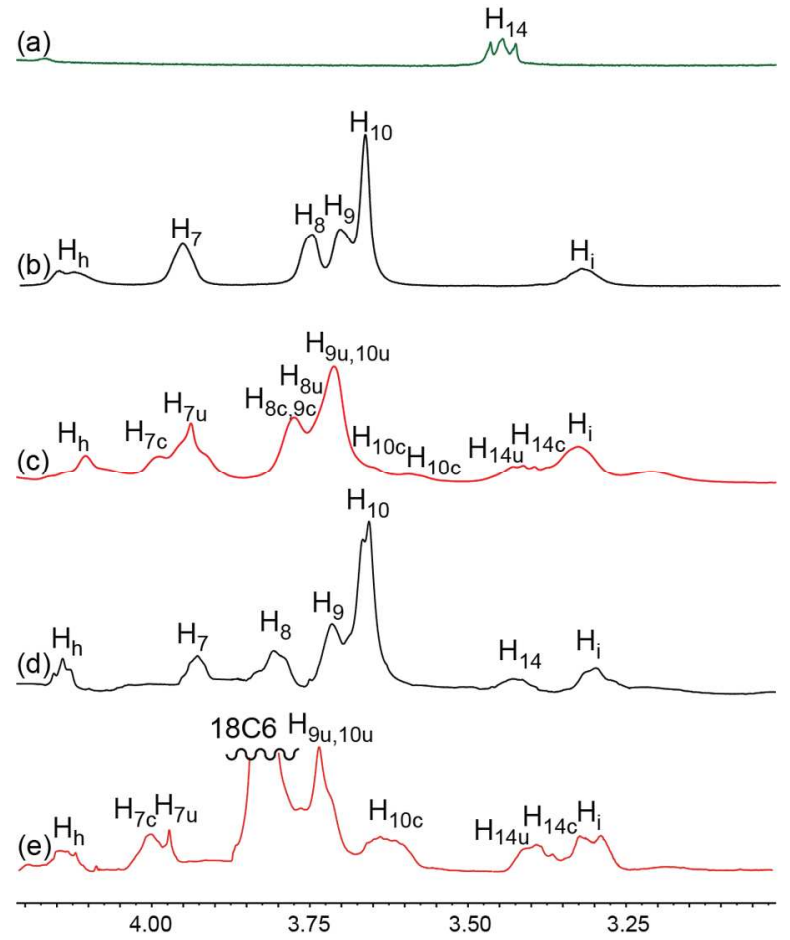

Figure S27. Partial ${ }^{1} \mathrm{H}$ NMR spectra $\left[400 \mathrm{MHz}, \mathrm{CD}_{2} \mathrm{Cl}_{2} / \mathrm{CD}_{3} \mathrm{NO}_{2}(1: 1, v / v), 298 \mathrm{~K}\right]$ of (a) dialkylammonium salt $\mathbf{4 b}$; (b) $\mathbf{1}$; (c) $\mathbf{5 b}$; (d) after addition of 1.5 equiv. of $\mathrm{KPF}_{6}$ to (c); and (e) after addition of 1.5 equiv. of $18 \mathrm{C} 6$ to (d). Here "c" and "u" denote complexed and uncomplexed moieties, respectively.

7. Self-healing properties of the supramolecular polymer network gel

(a)

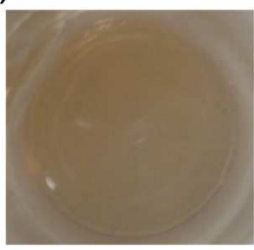

(b)

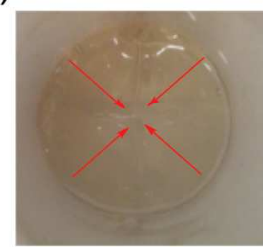

(c)

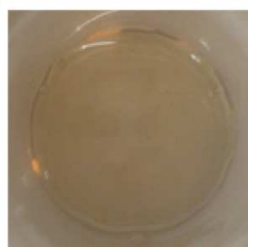

Figure S28. Photographs of self-healing process: (a) the supramolecular polymer gel; (b) after damage; (c) after free-standing for $3 \mathrm{~min}$.

When the gel was broken, it healed itself in a short time due to the synergic effect of H-bonding and metal-ligand coordination. 
8. Swelling experiments of $\mathbf{1}$ in dichloromethane
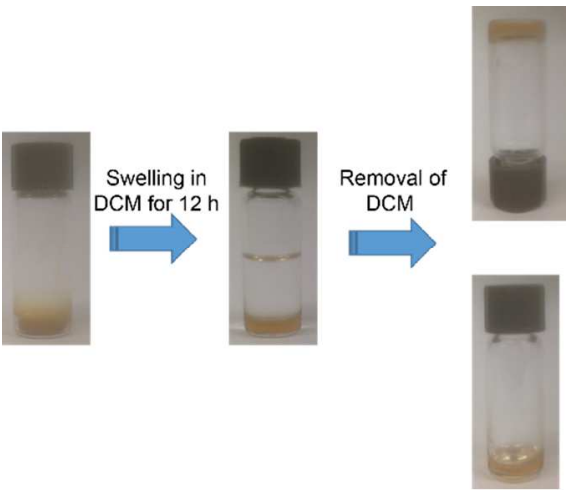

Figure S29. Swelling experiment of $\mathbf{1}$ in dichloromethane (DCM). Here, $Q$ is the degree of swelling; $m$ is the weight of the swelled sample; $m_{0}$ is the weight of the initial sample.

Degree of swelling $Q=\frac{m-m 0}{m 0}=\frac{74.61-13.05}{13.05}=4.72$

9. Comparison of ${ }^{1} \mathrm{H} N M R$ spectra of ligand 3 in $\mathrm{CD}_{2} \mathrm{Cl}_{2}$ and DMSO-d

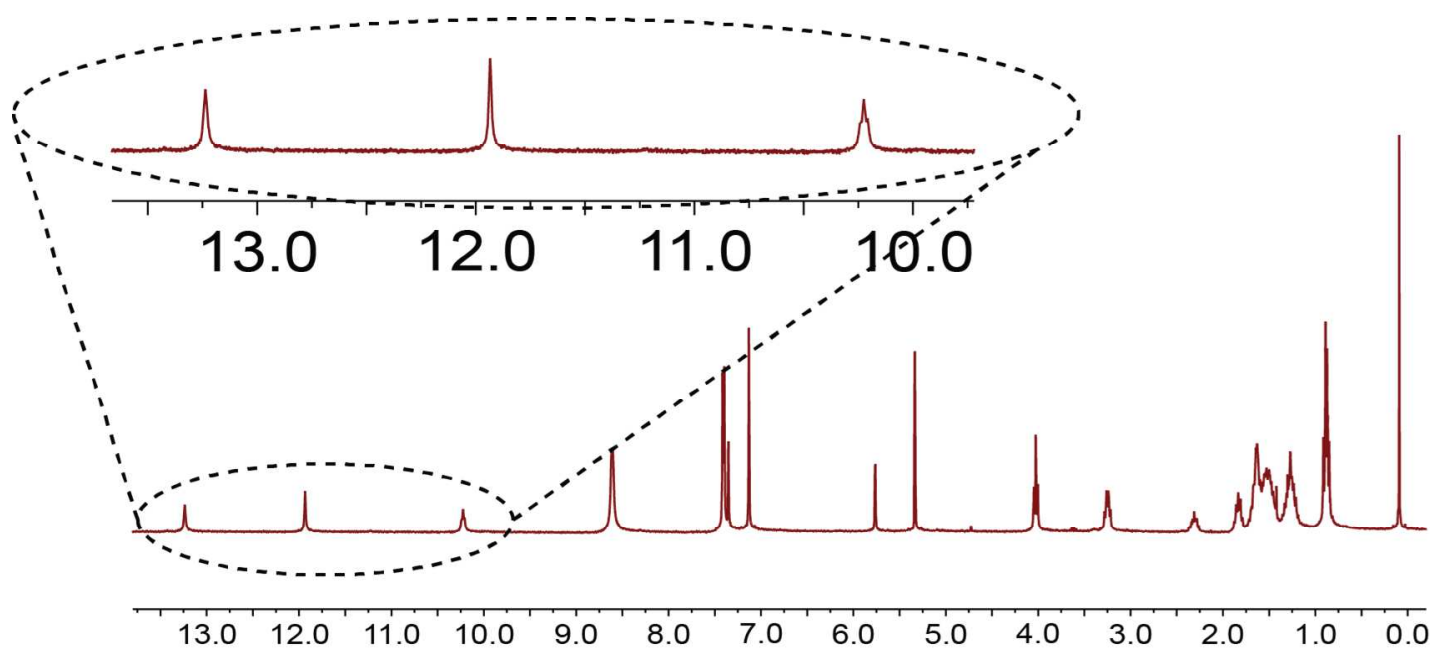

Figure S30. ${ }^{1} \mathrm{H}$ NMR spectra of ligand $\mathbf{3}\left(\mathrm{CD}_{2} \mathrm{Cl}_{2}, 400 \mathrm{MHz}, 298 \mathrm{~K}\right)$. 


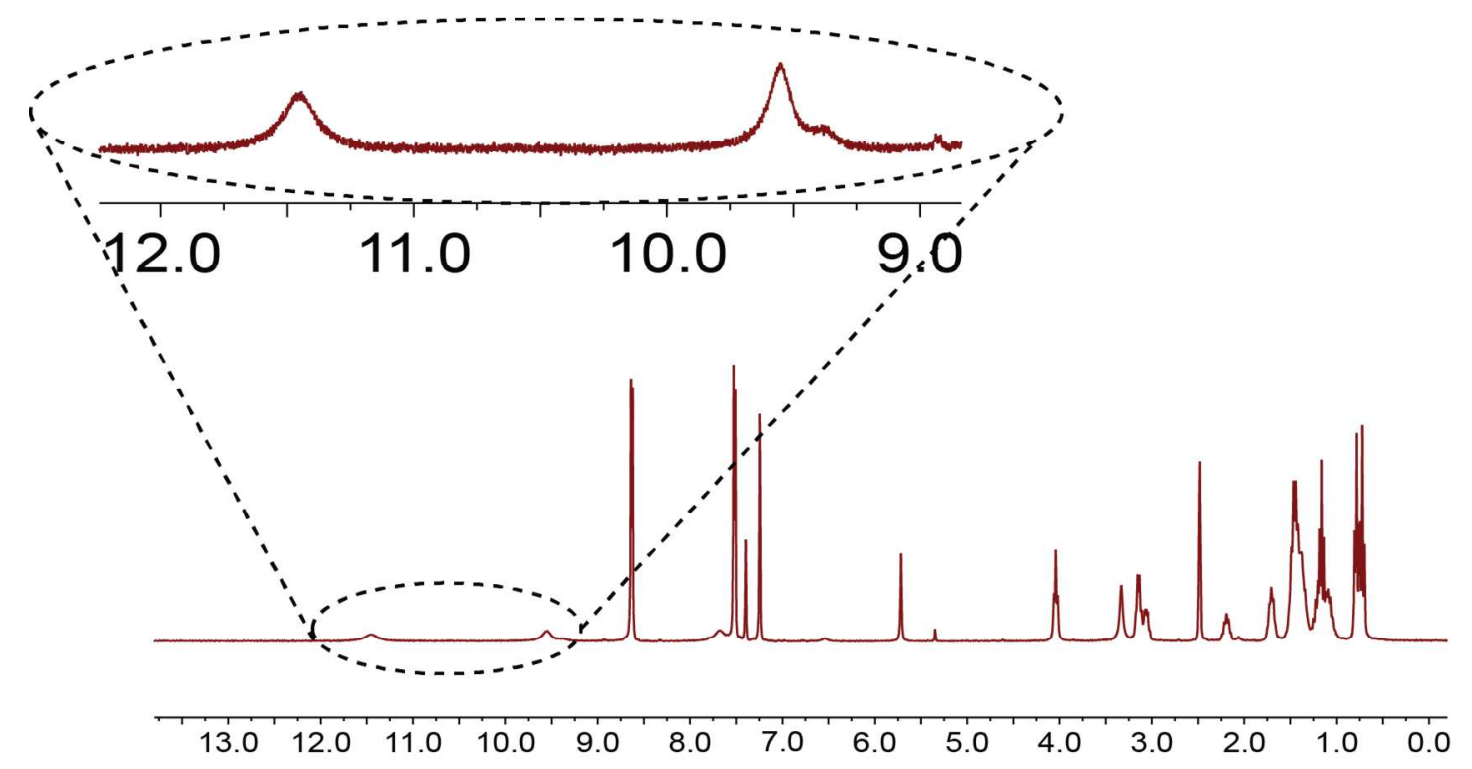

Figure S31. ${ }^{1} \mathrm{H}$ NMR spectra of ligand 3 (DMSO- $\left.d_{6}, 400 \mathrm{MHz}, 298 \mathrm{~K}\right)$.

As shown in Figure $\mathrm{S} 30$ and $\mathrm{S} 31$, in $\mathrm{CD}_{2} \mathrm{Cl}_{2}$ the signals corresponding to $\mathrm{N}-\mathrm{H}$ in the UPy moiety displayed large downfield shifts (observed between 10.0 and $13.5 \mathrm{ppm}$ ) and a lower intensity compared to the signals in DMSO, giving direct evidence for the formation of H-bonds between UPy groups. 


\section{References}

(S1) Yan, X.; Li, S.; Pollock, J. B.; Cook, T. R.; Chen, J.; Zhang, Y.; Ji, X.; Yu, Y.; Huang, F.; Stang, P. J. Proc. Natl. Acad. Sci. U.S.A. 2013, 110, 15585.

(S2) Lu, Q.; Li, X.; Li, J.; Yang, Z.; Xu, B.; Chi, Z.; Xu, J.; Zhang, Y. J. Mater. Chem. C 2015, 3, 1225.

(S3) Yan, X.; Cook, T. R.; Pollock, J. B.; Wei, P.; Zhang, Y.; Yu, Y.; Huang, F.; Stang, P. J. J. Am. Chem. Soc. 2014, $136,4460$.

(S4) Kikuchi, T.; Murase, T.; Sato, S.; Fujita, M. Supramol. Chem.2008, $20,81$. 